\title{
Employability portfolio voor bedrijfssectoren en bedrijven
}

Citation for published version (APA):

de Grip, A., \& Sanders, J. M. A. F. (2003). Employability portfolio voor bedrijfssectoren en bedrijven.

Researchcentrum voor Onderwijs en Arbeidsmarkt, Faculteit der Economische Wetenschappen. ROA Reports No. 2 https://doi.org/10.26481/umarep.2003002

Document status and date:

Published: 01/01/2003

DOI:

10.26481/umarep.2003002

Document Version:

Publisher's PDF, also known as Version of record

\section{Please check the document version of this publication:}

- A submitted manuscript is the version of the article upon submission and before peer-review. There can be important differences between the submitted version and the official published version of record.

People interested in the research are advised to contact the author for the final version of the publication, or visit the DOI to the publisher's website.

- The final author version and the galley proof are versions of the publication after peer review.

- The final published version features the final layout of the paper including the volume, issue and page numbers.

Link to publication

\footnotetext{
General rights rights.

- You may freely distribute the URL identifying the publication in the public portal. please follow below link for the End User Agreement:

www.umlib.nl/taverne-license

Take down policy

If you believe that this document breaches copyright please contact us at:

repository@maastrichtuniversity.nl

providing details and we will investigate your claim.
}

Copyright and moral rights for the publications made accessible in the public portal are retained by the authors and/or other copyright owners and it is a condition of accessing publications that users recognise and abide by the legal requirements associated with these

- Users may download and print one copy of any publication from the public portal for the purpose of private study or research.

- You may not further distribute the material or use it for any profit-making activity or commercial gain

If the publication is distributed under the terms of Article $25 \mathrm{fa}$ of the Dutch Copyright Act, indicated by the "Taverne" license above, 


\title{
Employability Portfolio voor bedrijfssectoren en bedrijven
}

\author{
ROA-R-2003/2
}

Andries de Grip

Jos Sanders

Researchcentrum voor Onderwijs en Arbeidsmarkt

Faculteit der Economische Wetenschappen en Bedrijfskunde Universiteit Maastricht

Maastricht, januari 2003 
Dit onderzoek is uitgevoerd in opdracht van het Ministerie van Economische Zaken

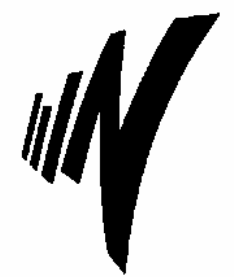

Ministerie van Economische Zaken

ISBN 90-5321-356-2

Sec02.139.doc 


\section{Inhoud}

Bladzijde

Voorwoord

Resumé

1 Inleiding 1

2 Naar een Sectorale Employability Portfolio 5

2.1 Het conceptuele model 6

2.2 Aandachtpunten bij de ontwikkeling van een Employability Portfolio $\begin{array}{ll}\text { voor sectoren en bedrijven } & 11\end{array}$

$\begin{array}{lll}2.3 & \text { De Portfolio-methodiek } & 14\end{array}$

2.4 Sectorale Employability Portfolio (SEP) 14

3 Employability Portfolio Chemie en Handel en reparatie 23

$\begin{array}{ll}3.1 \text { Databronnen } & 23\end{array}$

3.2 Lacunes in de op dit moment beschikbare informatie 26

3.3 De Employability Portfolio voor de sectoren Chemie en Handel en
Reparatie

4 Employability Portfolio Bedrijven 31

4.1 Employability Portfolio chemie 31

4.2 Employability Portfolio detailhandel 36

4.3 Positionering van de Employability Portfolio's 42

4.4 Mogelijkheden voor implementatie Employability Portfolio 46

$\begin{array}{ll}\text { Literatuur } & 49\end{array}$ 



\section{Voorwoord}

Dit rapport gaat in op de verschillende stappen die nodig zijn om te komen tot een benchmarkinstrument dat het voor de overheid, sociale partners, individuele bedrijven en brancheorganisaties mogelijk maakt structureel inzicht te krijgen in de ontwikkeling van de employability van het personeel, het employabilitybeleid en de prestaties van bedrijven en bedrijfssectoren. Dit inzicht in employability ontwikkeling, investeringen in HRM en prestaties van bedrijven en bedrijfssectoren maakt het op termijn mogelijk een helder antwoord te geven op de vraag in hoeverre investeringen in HRM lonend zijn. Het rapport beschrijft hiertoe de opzet van een tweetal instrumenten: de Sectorale Employability Portfolio en de Employability Portfolio Bedrijven.

De leiding van dit project was in handen van Prof. dr. A. de Grip. Drs. J. Sanders speelde een centrale rol bij het uitvoeren van het onderzoek. Wij zijn allereerst dank verschuldigd aan drs. L. Brinkman, drs. A.M. van der Laag, drs. M.W. van Meerbeek en drs. T.W. Wong (Ministerie van Economische Zaken) voor hun begeleiding en commentaar tijdens het onderzoek. Ook bedanken wij mevrouw A. LambertsJanssen (Stichting Arbeidsmarkt MKB), mevrouw F.M. Noordhoek (Vakcentrum Levensmiddelen), de heren H.K.H.B. Moust, J.M.G. Muijsers, W.J.H.P. van der Meulen en $H$. Hendrikx (DSM Limburg), de heer J.W. Koole (VNO/NCW), de heer H. Droppert (Wise Up Consultancy), de heer A.R.G. Schoonderwalt (AKZO Nobel) en de heer L. Taminiau (V\&D) voor hun inhoudelijke bijdrage aan het onderzoek. 



\section{Resumé}

Wat levert Human Resource Management (HRM) nu eigenlijk op? Een vraag die regelmatig wordt gesteld. Een vraag waarop van de HR manager of het hoofd Personeelszaken ook vrijwel altijd een positief antwoord volgt. Zelden of nooit is dat echter een met (financiële) kengetallen onderbouwd antwoord. De vraag zelf is, mede gezien het feit dat het economisch wat minder gaat en organisaties zich beraden op belangrijke kostenposten, echter zeer actueel.

Bedrijven en overheid zetten financiële middelen in om investeringen in menselijk kapitaal te realiseren c.q. te bevorderen. Met name wanneer er sprake is van snelle technologische ontwikkelingen, is het belangrijk dat deze investeringen in HRM en scholing vergroot worden, ook in tijden dat het economisch minder gaat. Daarbij is het belangrijk dat er een goed inzicht is in de rendementen van deze investeringen en de effecten ervan op de 'employability' van het personeel. Zowel het bedrijfsleven als de overheid hebben er dus belang bij dat een helder antwoord wordt geformuleerd op de vraag: "Loont HRM?".

Investeringen in het menselijk kapitaal kunnen op verschillende manieren plaatsvinden. In het rapport 'Loont het investeren in het personeel?' onderscheiden Van Loo en De Grip (2003) Human Resource Management (HRM), Human Resource Development (HRD) en opleidingsbeleid. HRM omvat alle activiteiten die erop gericht zijn het menselijk kapitaal optimaal in te zetten. Daaronder valt zowel het inzetten van beschikbaar menselijk kapitaal (doorstroombeleid) als het aantrekken van nieuw menselijk kapitaal (werving en selectie) als het afstoten van verouderd menselijk kapitaal (uitstroombeleid). HRD is in feite een onderdeel van het HRM beleid dat erop gericht is het door het bedrijf aangetrokken menselijk kapitaal verder te ontwikkelen. Het opleidingsbeleid van een organisatie vormt de kern van het HRD. Het opleidingsbeleid is gericht op de ontwikkeling van menselijk kapitaal door middel van scholingsactiviteiten.

Het investeren in HRM, HRD en opleidingsbeleid kan op verschillende manieren rendement opleveren voor een organisatie. Primair gaat het voor de meeste bedrijven echter steevast om rendement in de zin van een optimale financiële performance. In de huidige kenniseconomie, waarin de concurrentieslag steeds meer op basis van het menselijk kapitaal waarover organisaties beschikken wordt gevoerd, wint inzicht in vooral het financiële rendement dat bedrijven uit menselijk kapitaal halen en de manier waarop bedrijven dat doen dan ook steeds meer aan belang. Het financiële rendement van investeringen in menselijk kapitaal kan echter op zeer veel verschillende manieren worden gemeten en beoordeeld. Van Loo en De Grip ${ }^{1}$ geven hiervan een overzicht.

1. J.B. van Loo en A. de Grip (2002). Loont HRM? Een literatuurverkenning. ROA-R-2002/15, Maastricht. 
Ondanks het algemeen erkende belang van rendementsmeting voor investeringen in het menselijk kapitaal is empirisch onderzoek op dit gebied in Nederland opvallend schaars. Een belangrijke oorzaak hiervoor is dat het buitengewoon lastig blijkt om op basis van de bij bedrijven aanwezige personeelsinformatie te bepalen in hoeverre investeringen in het menselijk kapitaal nu daadwerkelijk renderen en de employability van het personeel bevorderen en in hoeverre organisatie- c.q. sectorkenmerken en andere elementen daarop van invloed zijn.

In dit rapport wordt om die reden een voorstel gedaan om te komen tot een benchmarkinstrument dat de potentie heeft de benodigde informatie op structurele wijze te leveren, zowel op het niveau van individuele bedrijven als geaggregeerde cijfers op sectorniveau. De centrale vraagstelling bij het inrichten van dit benchmarkinstrument is tweeledig:

1. op welke wijze kan inhoud worden gegeven aan een instrument op basis waarvan op sectoraal niveau de ontwikkeling van de employability van werkenden en de effectiviteit van het gevoerde HRM beleid in beeld kan worden gebracht?

2. op welke wijze kunnen individuele bedrijven de employability van hun personeel en de effectiviteit van het gevoerde HRM beleid benchmarken ten opzichte van andere bedrijven in hun sector?

Als antwoord op beide vragen wordt in dit rapport voorgesteld te komen tot een Sectorale Employability Portfolio (vraag 1) en een Employability Portfolio Bedrijven (vraag 2). Door structureel invulling te geven aan zowel SEP als EPB wordt allereerst beoogd ontwikkelingen in het employabilitybeleid van individuele bedrijven en sectoren in de tijd te volgen en te vergelijken. SEP en EPB bieden in potentie echter ook de mogelijkheid om causale relaties te leggen tussen investeringen in specifieke elementen van HRM, HRD en opleidingsbeleid en het door bedrijven (of sectoren) behaalde (financiële) rendement. Ten slotte beogen we met SEP en EPB de mogelijkheid te creëren om te kijken naar de effecten van maatschappelijke ontwikkelingen, of specifieke bedrijfs- en sectorkenmerken op het rendement van investeringen in HRM, HRD en opleidingsbeleid. De centrale doelstelling van dit instrument is het op termijn antwoorden kunnen geven op de vraag in hoeverre en onder welke omstandigheden investeringen in HRM het best renderen.

Dit rapport doet verslag van de stappen die zijn gezet in de ontwikkeling van de voorgestelde SEP en EPB.

\section{Naar een Sectorale Employability Portfolio (SEP)}

In het kader van de door overheid en sociale partners geformuleerde Employability agenda is door het Researchcentrum voor Onderwijs en Arbeidsmarkt (ROA) in opdracht van het Ministerie van Sociale Zaken en Werkgelegenheid een indicatorenstelsel $^{2}$ ontwikkeld dat de basis vormt voor de Sectorale Employability Portfolio. In

2. Zie A. de Grip en J. Sanders (2001), Naar een Employability Monitor, Elsevier, Den Haag/ Doetinchem.

iv 
het oorspronkelijke indicatorenstelsel wordt gekeken naar de in een organisatie aanwezige employability, de behoefte aan employability, de arbeidsmarktperspectieven van werknemers op grond van hun opleidingsachtergrond en de zogenaamde effectueringcondities. In de SEP komt de structuur van het oorspronkelijke indicatorenstelsel terug. Uit gesprekken met (potentiële) gebruikers van de informatie is echter gebleken dat op een vijftal punten aanpassingen gewenst zijn. Het gaat daarbij om:

1. toespitsing op kernindicatoren;

2. van relatieve cijfers naar absolute cijfers;

3. van monitor naar Employability Portfolio;

4. van alléén sectorniveau naar zowel sector- als bedrijfsniveau;

5. toevoegen prestatiemaatstaven.

Deze aanpassingen hebben tot de SEP geleid die in schema 1 is weergegeven.

Schema 1

Opzet Sectorale Employability Portfolio

\begin{tabular}{|c|c|}
\hline Aanwezige employability & Operationalisatie \\
\hline Opleidingsniveau & $\%$ werkenden met tenminste een MBO opleiding \\
\hline Werkervaring & $\begin{array}{l}\% \text { werkenden dat langer dan } 2 \text { jaar actief is op de } \\
\text { arbeidsmarkt }\end{array}$ \\
\hline Ervaringsconcentratie & $\begin{array}{l}\% \text { werkenden dat langer dan } 8 \text { jaar in de huidige functie } \\
\text { werkzaam is }\end{array}$ \\
\hline Opleidingsbereidheid & $\begin{array}{l}\text { \% werkenden dat een opleiding heeft gevolgd in de afgelopen } \\
\text { twee jaar }\end{array}$ \\
\hline \begin{tabular}{|l|} 
Functionele \\
mobiliteitsbereidheid
\end{tabular} & $\%$ werkenden dat van baan wil veranderen \\
\hline $\begin{array}{l}\text { Geografische } \\
\text { mobiliteitsbereidheid }\end{array}$ & $\begin{array}{l}\text { \% werkenden dat bereid is te verhuizen i.v.m. een nieuwe } \\
\text { functie }\end{array}$ \\
\hline Kwalitatieve inzetbereidheid & $\begin{array}{l}\% \text { werkenden dat indien nodig taken van buiten de functie op } \\
\text { zich zou willen nemen }\end{array}$ \\
\hline \begin{tabular}{|l|} 
Functionele \\
mobiliteitsinspanning
\end{tabular} & $\begin{array}{l}\% \text { werkenden dat in de afgelopen twee jaar van functie is } \\
\text { veranderd }\end{array}$ \\
\hline \begin{tabular}{|l|} 
Geografische \\
mobiliteitsinspanning
\end{tabular} & $\%$ werkenden dat op verschillende werklocaties actief is \\
\hline Kwalitatieve inzet & $\begin{array}{l}\% \text { werkenden dat vaak taken op zich neemt van buiten de } \\
\text { eigen functie }\end{array}$ \\
\hline Kwantitatieve inzet & $\%$ werkenden met onregelmatige werktijden \\
\hline Gezinssituatie belemmerend & $\%$ werkenden dat gehuwd is en thuiswonende kinderen heeft \\
\hline Gezondheid belemmerend & $\begin{array}{l}\% \text { werkenden dat zich als gevolg van de gezondheid } \\
\text { belemmerd voelt bij het uitoefenen van het werk }\end{array}$ \\
\hline Behoefte aan employability & Operationalisatie \\
\hline Demografische ontwikkelingen & ratio van ouderen $(>=50)$ en jongeren $(<=30$ jaar $)$ \\
\hline Economische ontwikkelingen & $\begin{array}{l}\text { mate waarin bedrijven gevoelig zijn voor conjuncturele } \\
\text { schommelingen }\end{array}$ \\
\hline Technologische vernieuwingen & $\begin{array}{l}\% \text { werkenden dat met een nieuwe techniek/ technologie is } \\
\text { gaan werken }\end{array}$ \\
\hline $\begin{array}{l}\text { Organisatorische } \\
\text { veranderingen }\end{array}$ & $\%$ werkenden dat wordt getroffen door reorganisaties \\
\hline
\end{tabular}


Schema 1 (vervolg)

Opzet Sectorale Employability Portfolio

\begin{tabular}{|c|c|c|c|}
\hline \multicolumn{2}{|c|}{ Behoefte aan employability } & \multicolumn{2}{|l|}{ Operationalisatie } \\
\hline \multicolumn{2}{|l|}{ Fysieke belasting } & \multicolumn{2}{|c|}{$\begin{array}{l}\% \text { werkenden dat a.g.v. lichamelijke belasting het werk } \\
\text { verzuimt }\end{array}$} \\
\hline \multicolumn{2}{|l|}{ Psychische belasting } & \multicolumn{2}{|c|}{$\%$ werkenden dat a.g.v. werkdruk het werk verzuimt } \\
\hline \multicolumn{2}{|l|}{ Conflicten } & \multicolumn{2}{|c|}{$\begin{array}{l}\text { \% werkenden dat a.g.v. conflicten met leidinggevenden of } \\
\text { collega's het werk verzuimt }\end{array}$} \\
\hline \multicolumn{4}{|c|}{ Arbeidsmarktperspectieven } \\
\hline \multicolumn{2}{|c|}{$\begin{array}{l}\text { (Zeer) goede } \\
\text { arbeidsmarktperspectieven }\end{array}$} & \multicolumn{2}{|c|}{$\begin{array}{l}\% \text { werkenden met (zeer) goede arbeidsmarktperspectieven } \\
\text { op basis van hun opleidingsachtergrond }\end{array}$} \\
\hline \multirow{2}{*}{ HRM faciliteiten } & \multicolumn{3}{|c|}{ Operationalisatie } \\
\hline & \multicolumn{2}{|c|}{ Beschikbaarheid } & Gebruik \\
\hline Kinderopvang & \multicolumn{2}{|c|}{$\begin{array}{l}\text { \% bedrijven dat faciliteiten } \\
\text { voor kinderopvang biedt }\end{array}$} & $\begin{array}{l}\% \text { werkenden dat gebruik maakt van } \\
\text { kinderopvang }\end{array}$ \\
\hline Opleiding & \multicolumn{2}{|c|}{$\begin{array}{l}\text { \% bedrijven met opleidings- } \\
\text { budget }\end{array}$} & $\begin{array}{l}\text { \% werkenden dat een door de werk- } \\
\text { gever betaalde opleiding heeft gevolgd }\end{array}$ \\
\hline Zorg en arbeid & \multicolumn{3}{|c|}{$\%$ werkenden dat werktijden goed kan afstemmen op de thuissituatie } \\
\hline Functieroulatie & \multicolumn{3}{|c|}{$\%$ bedrijven dat beleid voert op het gebied van taak of functieroulatie } \\
\hline Ouderenbeleid & \multicolumn{3}{|c|}{$\%$ bedrijven dat een ouderenbeleid heeft uitgewerkt } \\
\hline ARBO/verzuim & \multicolumn{3}{|c|}{$\%$ bedrijven dat een ARBO/verzuimplan heeft uitgewerkt } \\
\hline \multirow[t]{2}{*}{ Reïntegratie } & \multicolumn{3}{|c|}{$\%$ bedrijven dat een reïntegratieprotocol heeft uitgewerkt } \\
\hline & \multicolumn{3}{|c|}{ Kwaliteit van de HRM faciliteiten } \\
\hline POP & \multicolumn{3}{|c|}{ \% werkenden waarvoor POP's zijn opgesteld } \\
\hline Functioneringsgesprek & \multicolumn{3}{|c|}{$\begin{array}{l}\text { \% werkenden waarmee jaarlijks functioneringsgesprekken worden } \\
\text { gevoerd }\end{array}$} \\
\hline Ondersteuning & \multicolumn{3}{|c|}{$\%$ werkenden met voldoende ondersteuning van de leidinggevende } \\
\hline \multicolumn{2}{|l|}{ Prestatiemaatstaven } & \multicolumn{2}{|l|}{ Operationalisatie } \\
\hline \multicolumn{2}{|c|}{ Werknemerstevredenheid } & \multicolumn{2}{|c|}{$\%$ werkenden dat (zeer) tevreden is met de huidige functie } \\
\hline \multicolumn{2}{|l|}{ Verzuim } & \multicolumn{2}{|c|}{$\%$ werkenden dat werk verzuimt, exclusief zwangerschap } \\
\hline \multicolumn{2}{|l|}{ Personeelsverloop } & \multicolumn{2}{|c|}{$\%$ werkenden dat de organisatie heeft verlaten } \\
\hline Wervingskracht & & $\%$ moeilijk vervulb & are vacatures op aantal werkenden \\
\hline Productiviteit & & omzet per werken & \\
\hline Resultaat & & resultaat voor bela & astingheffing per werkende \\
\hline
\end{tabular}

Deze opzet van het SEP maakt het niet alleen mogelijk de ontwikkeling van de employability van de werknemers en de employability behoefte in de verschillende bedrijfssectoren te monitoren, maar biedt ook de mogelijkheid inzicht te krijgen in de effecten van het gevoerde HRM beleid op het functioneren van een bepaalde bedrijfssector.

\section{Invulling geven aan de SEP}

De Sectorale Employability Portfolio is zo volledig mogelijk ingevuld voor twee bedrijfssectoren: de chemie en de sector handel en reparatie (zie tabel 3.1 en 3.2). 
Daarbij is gebruik gemaakt van een aantal bestaande databronnen, te weten:

- $\quad$ arbeidsaanbodpanel (OSA);

- $\quad$ arbeidsvraagpanel (OSA);

- $\quad$ enquête Beroepsbevolking/ EBB (CBS);

- bedrijfsopleidingenenquête/ BOE (CBS);

- $\quad$ permanent Onderzoek Leefsituatie/ POLS (CBS);

- de Arbeidsmarkt naar Opleiding en Beroep/ ANOB (ROA).

Voor een aantal indicatoren is vooralsnog geen bruikbare informatie beschikbaar:

- $\quad$ verhuisbereidheid (aanwezige employability);

- functionele mobiliteitsinspanning (aanwezige employability);

- $\quad$ POP (HRM faciliteiten);

- functioneringsgesprek (HRM faciliteiten);

- $\quad$ productiviteit (Prestatiemaatstaven);

- resultaat (Prestatiemaatstaven).

Naast het feit dat het uiteraard van groot belang is dat deze hiaten in de informatie op korte termijn kunnen worden ingevuld, is het bovendien van belang dat de informatie die in de portfolio('s) is opgenomen met enige regelmaat kan worden geactualiseerd. Voor de hand ligt een tweejaarlijkse actualisering, omdat het merendeel van de bij de invulling van de SEP gebruikte databronnen tweejaarlijks of jaarlijks wordt geactualiseerd.

\section{De SEP voor de sector Chemie en Handel en Reparatie}

De Portfolio voor de sector Chemie laat zien dat de sector in vergelijking met andere sectoren op vrijwel alle indicatoren gemiddeld scoort. De meest gunstige score heeft de sector voor de functieroulatie van de werkenden in de sector. Dat betekent dat in veel bedrijven in de sector chemie werknemers zonder veel omschakeltijd elkaars werk overnemen. Dit geeft aan dat er sprake is van een brede inzetbaarheid. De sector heeft bovendien het laagste verzuim vanwege conflicten met leidinggevenden of collega's. Daartegenover staat wel dat de sector wordt gekenmerkt door de laagste werknemerstevredenheid.

De Portfolio voor de sector Handel en Reparatie laat zien dat met name het hoge verlooppercentage en het relatief lage percentage werknemers dat werkervaring heeft opgebouwd om extra aandacht vragen. Waarschijnlijk hangt een en ander samen met het feit dat veel werkenden in de sector relatief jong zijn. De employability behoefte vanwege de vergrijzing van het personeel is in deze sector dan ook het geringste van alle sectoren. De aandacht voor ouderenbeleid in de sector Handel en Reparatie is, waarschijnlijk mede daardoor, erg beperkt.

\section{Naar een Employability Portfolio Bedrijven (EPB)}

Om te kunnen bepalen in hoeverre de Sectorale Employability Portfolio (SEP) de basis zou kunnen vormen voor een voor individuele bedrijven als benchmark voor hun personeelsbeleid te gebruiken Employability Portfolio Bedrijven (EPB), is in de 
gesprekken met potentiële gebruikers (sleutelpersonen uit de chemiesector en de detailhandel) ook ingegaan op de vraag in hoeverre de SEP voorziet in de informatiebehoefte die bedrijven binnen een sector hebben om zich aan elkaar en de sector als geheel te spiegelen.

De gesprekken in het veld maken boven alles duidelijk dat de informatiebehoefte per sector op een aantal punten verschillend is. Dat heeft ertoe geleid dat voor de opzet van de EPB's is gekozen voor één (kern)deel dat voor alle sectoren dezelfde informatie oplevert (schema 2) en een deel dat voorziet in de sectorspecifieke informatiebehoefte, zoals die door de vertegenwoordigers van respectievelijk de chemiesector en de detailhandel is aangegeven (schema $3 a$ en $3 b$ ).

Schema 2

Kerngedeelte van Employability Portfolio Bedrijven

\begin{tabular}{|c|c|}
\hline Aanwezige employability & Operationalisatie \\
\hline Opleidingsniveau & $\%$ werkenden met tenminste een MBO opleiding \\
\hline Werkervaring & $\begin{array}{l}\% \text { werkenden dat langer dan } 2 \text { jaar actief is op de } \\
\text { arbeidsmarkt }\end{array}$ \\
\hline Ervaringsconcentratie & $\begin{array}{l}\% \text { werkenden dat langer dan } 8 \text { jaar in de huidige } \\
\text { functie werkzaam is }\end{array}$ \\
\hline Functionele mobiliteitsbereidheid & $\%$ werkenden dat van baan wil veranderen \\
\hline Verhuisbereidheid & $\begin{array}{l}\% \text { werkenden dat bereid is te verhuizen i.v.m. een } \\
\text { nieuwe functie }\end{array}$ \\
\hline Opleidingsbereidheid & $\begin{array}{l}\% \text { werkenden dat een opleiding heeft gevolgd in } \\
\text { de afgelopen } 2 \text { jaar }\end{array}$ \\
\hline Kwalitatieve inzetbereidheid & $\begin{array}{l}\% \text { werkenden dat indien nodig taken van buiten de } \\
\text { functie op zich zou willen nemen }\end{array}$ \\
\hline Functionele mobiliteitsinspanning & $\begin{array}{l}\% \text { werkenden dat in de afgelopen twee jaar van } \\
\text { functie is veranderd }\end{array}$ \\
\hline Kwalitatieve inzet & $\begin{array}{l}\% \text { werkenden dat vaak taken op zich neemt van } \\
\text { buiten de eigen functie }\end{array}$ \\
\hline Kwantitatieve inzet & $\%$ werkenden met onregelmatige werktijden \\
\hline Gezinssituatie belemmerend & $\begin{array}{l}\% \text { werkenden gehuwd (samenwonend) met } \\
\text { thuiswonende kinderen < } 17 \text { jaar }\end{array}$ \\
\hline Gezondheid belemmerend & $\begin{array}{l}\text { \% werkenden dat zich a.g.v. de gezondheid } \\
\text { belemmerd voelt bij het uitoefenen van het werk }\end{array}$ \\
\hline Demografische ontwikkelingen & ratio van ouderen $(>=50)$ en jongeren $(<=30)$ \\
\hline Economische ontwikkelingen & $\begin{array}{l}\text { mate waarin bedrijf gevoelig is voor conjuncturele } \\
\text { schommelingen }\end{array}$ \\
\hline Technologische vernieuwingen & $\begin{array}{l}\% \text { werkenden dat met een nieuwe techniek/ } \\
\text { technologie is gaan werken }\end{array}$ \\
\hline Organisatorische veranderingen & $\begin{array}{l}\% \text { werkenden dat wordt getroffen door } \\
\text { reorganisaties }\end{array}$ \\
\hline $\begin{array}{l}\text { Verzuim vanwege belastende } \\
\text { arbeidsomstandigheden }\end{array}$ & $\begin{array}{l}\% \text { werkenden dat vanwege belasting het werk } \\
\text { verzuimt }\end{array}$ \\
\hline
\end{tabular}


Schema 2 (vervolg)

Kerngedeelte van Employability Portfolio Bedrijven

\begin{tabular}{|c|c|c|}
\hline \multicolumn{2}{|c|}{ Arbeidsmarktperspectieven } & Operationalisatie \\
\hline \multicolumn{2}{|l|}{ Arbeidsmarktperspectieven } & $\begin{array}{l}\% \text { werkenden met (zeer) goede perspectieven } \\
\text { op basis van hun opleidingsachtergrond }\end{array}$ \\
\hline \multicolumn{2}{|l|}{ HRM faciliteiten } & Operationalisatie \\
\hline \multicolumn{3}{|l|}{ Beschikbaarheid en gebruik } \\
\hline $\begin{array}{l}\text { Beschikbaarheid } \\
\text { kinderopvang }\end{array}$ & \multicolumn{2}{|c|}{ biedt bedrijf faciliteiten voor kinderopvang } \\
\hline Gebruik kinderopvang & \multicolumn{2}{|c|}{$\%$ werkenden dat gebruik maakt van kinderopvang } \\
\hline $\begin{array}{l}\text { Beschikbaarheid } \\
\text { opleidingsfaciliteiten }\end{array}$ & \multicolumn{2}{|c|}{ heeft bedrijf een vastgesteld opleidingsbudget } \\
\hline Opleidingsparticipatie & \multicolumn{2}{|c|}{$\begin{array}{l}\% \text { werkenden dat een door de werkgever betaalde opleiding } \\
\text { heeft gevolgd }\end{array}$} \\
\hline Zorg en arbeid & \multicolumn{2}{|c|}{$\begin{array}{l}\% \text { werkenden dat werktijden goed kan afstemmen op de } \\
\text { thuissituatie }\end{array}$} \\
\hline Functieroulatie & \multicolumn{2}{|c|}{ voert bedrijf beleid op het gebied van taak- of functieroulatie } \\
\hline Ouderenbeleid & \multicolumn{2}{|c|}{ voert bedrijf ouderenbeleid } \\
\hline ARBO/verzuim & \multicolumn{2}{|c|}{ heeft bedrijf ARBO/ verzuimplan uitgewerkt } \\
\hline Reïntegratie & \multicolumn{2}{|c|}{ heeft bedrijf reïntegratieplan uitgewerkt } \\
\hline \multicolumn{3}{|l|}{ Kwaliteit } \\
\hline POP & \multicolumn{2}{|c|}{$\%$ werkenden waarvoor POP is opgesteld } \\
\hline Functioneringsgesprek & \multicolumn{2}{|c|}{$\begin{array}{l}\% \text { werkenden waarmee jaarlijks functioneringsgesprekken } \\
\text { worden gevoerd }\end{array}$} \\
\hline Ondersteuning & \multicolumn{2}{|c|}{$\begin{array}{l}\% \text { werkenden met voldoende ondersteuning van de } \\
\text { leidinggevende }\end{array}$} \\
\hline Prestatiemaatstaven & \multirow{2}{*}{\multicolumn{2}{|c|}{$\begin{array}{c}\text { Operationalisatie } \\
\% \text { werkenden dat (zeer) tevreden is met de huidige functie }\end{array}$}} \\
\hline Werknemerstevredenheid & & \\
\hline Verzuim & \multicolumn{2}{|c|}{$\%$ werkenden dat werk verzuimt, exclusief zwangerschap } \\
\hline Personeelsverloop & \multicolumn{2}{|c|}{$\%$ werkenden dat de organisatie heeft verlaten } \\
\hline Wervingskracht & \multicolumn{2}{|c|}{$\%$ moeilijk vervulbare vacatures op het aantal werkenden } \\
\hline Productiviteit & \multicolumn{2}{|c|}{ omzet per werkende } \\
\hline Resultaat & \multicolumn{2}{|c|}{ resultaat voor belastingheffing per werkende } \\
\hline
\end{tabular}

Ten opzichte van de SEP in schema 1 is de EPB in schema 2 slechts op één van de eerder besproken punten gewijzigd. Er wordt in de EPB naar aanleiding van de gevoerde gesprekken binnen de chemie en de detailhandel namelijk niet langer een onderscheid gemaakt tussen verzuim vanwege psychische belasting en verzuim vanwege fysieke belasting. In de SEP is dat nog wel het geval. Een belangrijk argument voor de keuze om de scheiding in het stelsel voor sectoren te handhaven is dat er van overheidswege een toenemende en blijvende aandacht zal moeten zijn voor het beperken van de instroom in de WAO. Daartoe is informatie nodig, die zo specifiek mogelijk is. Door de scheiding in de SEP te handhaven blijft het mogelijk om op sectorniveau te bepalen in hoeverre investeringen in ARBO beleid en verzuimbeleid (onderdelen van HRM) 'Ionen'. 
Ook de variabele ervaringsconcentratie is naar aanleiding van de gevoerde gesprekken ten opzichte van het oorspronkelijke model anders geoperationaliseerd. Die verandering is echter ook in de SEP doorgevoerd. In plaats van te kijken naar het percentage werknemers dat langer in de functie verblijft dan de gemiddelde werknemer in Nederland is voor een meer absolute maatstaf gekozen, namelijk het percentage werknemers in een sector of bedrijf dat meer dan acht jaar in één en dezelfde functie werkzaam is. Deze wijziging maakt het mogelijk om autonome veranderingen in de mate waarin ervaringsconcentratie zich voordoet te volgen.

Schema 3a

Sectorspecifieke informatie in Employability Portfolio Bedrijven, Chemie

\begin{tabular}{|l|l|}
\hline \multicolumn{1}{|c|}{$\begin{array}{c}\text { Gewenste informatie } \\
\text { sector Chemie }\end{array}$} & \multicolumn{1}{c|}{ Operationalisatie } \\
\hline $\begin{array}{l}\text { (Bedrijfs)interne mobiliteitsbereidheid } \\
\text { (aanwezige employability) }\end{array}$ & $\begin{array}{l}\text { \% werkenden dat bereid is van baan te } \\
\text { veranderen binnen de organisatie }\end{array}$ \\
\hline Binding (prestatiemaatstaf) & $\begin{array}{l}\text { \% werkenden dat er trots op is voor het } \\
\text { bedrijf te werken }\end{array}$ \\
\hline Arbeidsmarkt (prestatiemaatstaf) & $\begin{array}{l}\text { \% werkenden dat denkt (zeer) gemakkelijk } \\
\text { elders in de sector aan de slag te kunnen }\end{array}$ \\
\hline \multicolumn{2}{|l}{} \\
\hline
\end{tabular}

Schema $3 b$

Sectorspecifieke informatie in Employability Portfolio Bedrijven, Detailhandel

\begin{tabular}{|l|l|}
\hline \multicolumn{1}{|c|}{$\begin{array}{c}\text { Gewenste informatie } \\
\text { Detailhandel }\end{array}$} & \multicolumn{1}{c|}{ Operationalisatie } \\
\hline Bedrijfsomvang (controle) & aantal werkenden in uw bedrijf (vestiging) \\
\hline Onderbenutting (aanwezige employability) & $\begin{array}{l}\text { \% werkenden dat vindt dat zijn of haar } \\
\text { competenties onvoldoende worden benut }\end{array}$ \\
\hline Pendelbereidheid (aanwezige employability) & $\begin{array}{l}\text { maximale reistijd die werknemers willen } \\
\text { accepteren }\end{array}$ \\
\hline Loon boven CAO (HRM faciliteiten) & $\begin{array}{l}\text { \% werkenden met een loon dat hoger is dan } \\
\text { het volgens de CAO verplichte loon }\end{array}$ \\
\hline Doorstroom hulparbeiders & $\begin{array}{l}\text { \% hulparbeiders (weekendhulp, } \\
\text { vakantiekracht etc.) dat ook na afronding } \\
\text { (prestatiemaatstaf) }\end{array}$ \\
\hline Klanttevredenheid (prestatiemaatstaf) & $\begin{array}{l}\text { \% klanten dat (zeer) tevreden is over de } \\
\text { dienstverlening van het bedrijf }\end{array}$ \\
\hline \multicolumn{2}{|c}{} \\
\hline
\end{tabular}

\section{Mogelijkheden voor implementatie Employability Portfolio}

Om de Employability Portfolio te kunnen implementeren is het vanzelfsprekend noodzakelijk dat er in de verschillende bedrijfssectoren en bedrijven voldoende draagvlak voor is. Zowel in de Chemie als in de Detailhandel is uit de gesprekken gebleken dat er een duidelijke belangstelling bestaat voor het ontwikkelen van een benchmarkinstrument, zoals dat in dit rapport is beschreven. 
Cruciaal bij de implementatie van de Employability Portfolio is echter dat de belasting die het voor bedrijven met zich meebrengt om de vereiste informatie aan te leveren beperkt blijft tot een minimum. Wat dat betreft kunnen de in dit rapport gepresenteerde Employability Portfolio's ook worden gezien als een lijst van in principe relevante indicatoren waaruit een bedrijfssector een keuze kan maken of bepaalde accenten kan leggen.

Er zijn in principe twee mogelijkheden om de voor de Employability Portfolio vereiste informatie te verzamelen:

- $\quad$ aanlevering door de bedrijven zelf via enquêtering (bedrijfsenquête en personeelsenquête);

- verzameling van de vereiste informatie via employability consultants.

De eerste optie is vooral interessant voor sectoren waarin relatief veel grote bedrijven actief zijn. Niet alleen hebben deze bedrijven meestal professionele HRM'ers in dienst die belangstelling hebben voor de employabilityproblematiek, maar bovendien beschikken grotere bedrijven over (meer) en gemakkelijker toegankelijke administratieve gegevens. Invullen van een enquête zou daardoor eenvoudiger en minder belastend zijn.

De voor de Employability Portfolio vereiste informatie zou ook kunnen worden verzameld op soortgelijke wijze als dat dat in de Arbeidsmarktmonitor Metalektro gebeurt. In het kader van deze arbeidsmarktmonitor beantwoorden de hoofden P\&O van een groot aantal bedrijven in de metaal en elektrotechniek vier maal per jaar via internet een korte vragenlijst. Deze vragenlijst richt zich op een viertal aandachtspunten:

- $\quad$ knelpunten op de arbeidsmarkt;

- $\quad$ verschuivingen in de gevraagde competenties;

- instroom en uitstroom van personeel;

- $\quad$ employability van het personeel.

De informatie die in arbeidsmarktmonitoren wordt verzameld is vooral sectorspecifiek van aard. Afstemming met het conceptuele model voor de Employability Portfolio is daarom noodzakelijk. Voor de sector metaal- en elektrotechniek zouden kleine aanpassingen in de vragenlijsten echter al voldoende zijn om de invulling van de Employability Portfolio's mogelijk te maken.

\section{Informatieverzameling via consultants}

Met name voor sectoren waar veel kleine en middelgrote bedrijven actief zijn, zoals de detailhandel, zou de informatie die vereist is voor de employability portfolio van het bedrijf het beste verzameld kunnen worden door employability consultants of adviseurs. Hierbij zou kunnen worden aangesloten bij bestaande informatiekanalen of onderzoek binnen sectoren of branches. Belangrijk voor een optimale invulling van de Employability Portfolio's is wel dat afgezien van de mogelijkheid voor sector- 
specifieke accenten in principe in álle sectoren en branches vergelijkbare informatie wordt verzameld. Enige centrale coördinatie is daarbij van groot belang.

\section{Pilotprojecten}

In principe zouden langs beide lijnen pilotprojecten kunnen worden gestart om te komen tot de voorgestelde Employability Portfolio's. De pilotprojecten zouden kunnen fungeren als 'best practices', om zo andere, meer terughoudende sectoren te overtuigen van het belang van de beschikbaar gemaakte informatie. In deze pilotprojecten zou ook aansluiting kunnen worden gezocht bij bijvoorbeeld het Investors in People certificatietraject.

Het is wenselijk om alle doelgroepen op macro, meso en micro-niveau die belang hebben bij het tot stand komen van Employability Portfolio's bij deze pilotprojecten te betrekken. Daarbij gaat het, zoals gezegd, om de gebruikers van de informatie op drie niveaus; het sociaal-economische c.q. arbeidsmarktbeleid (overheid en sociale partners), bedrijfstakken (branche-organisaties, sociale partners) en individuele bedrijven (directie, HRM functionarissen, Ondernemingsraad). 


\section{Inleiding}

Het Human Resources Management (HRM) beleid van bedrijven en instellingen staat al jaren volop in de belangstelling. Deze belangstelling wordt gevoed door de idee dat het menselijk kapitaal binnen organisaties steeds meer de doorslaggevende factor is in de onderlinge concurrentiestrijd. Het HRM is er dan ook primair op gericht het menselijk kapitaal binnen organisaties geschikt te maken en te houden voor de veranderende eisen die aan het personeel worden gesteld.

In dit kader krijgt ook de employability van het personeel de laatste jaren steeds meer aandacht. Daarbij staat het optimaliseren van de arbeidsparticipatie en de arbeidsproductiviteit centraal. Echter, bij het bepalen van de mate waarin bedrijven succesvol zijn, staat de vergelijking van gegevens over het menselijke kapitaal waarover bedrijven de beschikking hebben steevast op een tweede plan. Gezien het belang van menselijk kapitaal in de huidige kenniseconomie wordt de roep om een methode om menselijk kapitaal te vergelijken steeds luider. ${ }^{3}$

In dit rapport zal worden verkend op welke wijze op deze lacune kan worden ingespeeld door het ontwikkelen van een benchmarkinstrument gericht op de employability van het personeel van bedrijven en het in dat kader gevoerde HRM beleid. De centrale vraagstelling hierbij is tweeledig:

1. op welke wijze kan inhoud worden gegeven aan een benchmarkinstrument op basis waarvan op sectoraal niveau de ontwikkeling van de employability van werkenden en de effectiviteit van het gevoerde HRM beleid in beeld kan worden gebracht?

2. op welke wijze kunnen individuele bedrijven de employability van hun personeel en de effectiviteit van het gevoerde HRM beleid benchmarken ten opzichte van andere bedrijven in hun sector?

Het is lastig is om de employability van werkenden in absolute termen te meten. Mede daarom is het Researchcentrum voor Onderwijs en Arbeidsmarkt (ROA) enkele jaren geleden gestart met de constructie van een Sectorale Employability Index (SEI). ${ }^{4}$ In deze SEI wordt een beeld gegeven van de employability van de werkenden in verschillende bedrijfssectoren ten opzichte van de employability van alle werkenden in alle bedrijfssectoren bij elkaar. Het conceptuele model van de SEI is vervolgens verder uitgewerkt in een sectorale Employability Monitor. ${ }^{5}$ Ook in deze Employability Monitor staan relatieve cijfers centraal, met als primair doel te kunnen zien hoe de employability van de werkenden in een bepaalde sector er voor staat in vergelijking met andere sectoren. Aan de basis van de Monitor staat echter een uitgebreid stelsel van indicatoren, dat ook de basis vormt voor het in dit rapport te

3. Zie ook Ministerie van Economische Zaken, Toets op het concurrentievermogen: op de drempel van het nieuwe millennium, Den Haag, SDU Uitgevers, 2000.

4. Zie A. de Grip, J. van Loo en J. Sanders (1998), Employability in bedrijf: naar een Employability Index voor bedrijfssectoren, ROA-R-1998/10, Maastricht.

5. Zie A. de Grip en J. Sanders (2001), Naar een Employability Monitor, Elsevier, Den Haag/ Doetinchem. 
ontwikkelen benchmarkinstrument in de vorm van een zogenaamde portfolio analyse.

Omdat in deze studie wordt voortgebouwd op het conceptuele raamwerk van de SEI en de Employability Monitor zal allereerst in hoofdstuk 2 het conceptuele raamwerk voor deze monitor kort de revue passeren. Dit raamwerk vormt immers de basis voor de twee in dit rapport te ontwikkelen employability portfolio's:

- Sectorale Employability Portfolio (SEP);

- Employability Portfolio Bedrijven (EPB).

Daarna wordt in paragraaf 2.2 ingegaan op de punten waarop bij de ontwikkeling van een Employability Portfolio moet worden gelet, om te komen tot een krachtig benchmarkinstrument. Dit benchmarkinstrument zal niet alleen de mogelijkheid moeten bieden om de ontwikkeling van de employability van werknemers in specifieke bedrijfssectoren en bedrijven te volgen, maar ook inzicht moeten geven in de effecten van het gevoerde HRM beleid op het functioneren van een bedrijf. Om dit doel te kunnen bereiken is het nodig om ook meer zicht te krijgen op de 'performance' van bedrijven. Daarbij zijn, zo blijkt ook uit de gevoerde gesprekken met sleutelfiguren, niet alleen financiële performance indicatoren, zoals de winstgevendheid, van belang, maar bijvoorbeeld ook factoren als de productiviteit, het personeelsverloop, ziekteverzuim, en bijvoorbeeld de werknemerstevredenheid. Paragraaf 2.3 schetst de voordelen van de portfolio methodiek, waarna in paragraaf 2.4 nader wordt ingegaan op de Sectorale Employability Portfolio.

De SEP is erop gericht om aan de hand van een aantal centrale indicatoren een beeld te geven van de verschillende aspecten van de employability ontwikkelingen in een bedrijfssector. In deze Sectorale Employability Portfolio staat de monitorring van de ontwikkelingen van de employability en het employability beleid van een sector centraal en niet, zoals in de SEI en de Employability Monitor het geval was, de stand van zaken van de ene sector ten opzichte van de andere bedrijfssectoren. In hoofdstuk 2 wordt de opzet van de SEP beschreven.

In hoofdstuk 3 van het rapport zal vervolgens geprobeerd worden de SEP zo volledig mogelijk in te vullen voor de sectoren chemie en handel en reparatie. De sector chemie is op grond van de eerdere Employability Monitor te beschouwen als een best-practices sector op het gebied van het employability beleid. Voor handel en reparatie is gekozen, omdat in deze sector relatief veel midden- en kleinbedrijf (MKB) actief is, waarvoor het in de praktijk vaak veel moeilijker is invulling te geven aan het employability beleid. Eerst wordt ingegaan op de bestaande databronnen en de lacunes in de daarin beschikbare informatie. Daarna wordt de SEP voor de chemie en de sector handel en reparatie gepresenteerd.

In de gevolgde portfolio-benadering wordt er naar gestreefd een aantal indicatoren te formuleren. Elke indicator staat voor een specifiek aspect van de employability van het personeel en het gevoerde employability beleid. Om ook het benchmarken tussen de verschillende bedrijfssectoren mogelijk te maken, worden telkens ter vergelijking ook de zogenaamde 'top- en bottom' waarde worden vermeld van de op 
het desbetreffende punt het best en slechtst scorende sector. Hoofdstuk 3 levert dus voor de sectoren chemie en handel en reparatie een portfolio op van gegevens die richtpunten kunnen vormen voor het te voeren beleid op het gebied van het Human Resources Management (HRM) in de sector.

In het vierde hoofdstuk van dit rapport wordt vervolgens de vertaalslag gemaakt van het sectorniveau naar het individuele bedrijfsniveau. Onderzocht wordt wat de mogelijkheden zijn om vanuit de SEP te komen tot een instrument waarmee individuele bedrijven hun positie met betrekking tot bepaalde kernaspecten van de employability van hun medewerkers kunnen vergelijken met de sector waarin zij opereren. Bovendien wordt in dit hoofdstuk ingegaan op de mogelijkheden voor individuele bedrijven om de vorderingen die zij maken op bepaalde kernaspecten van de employability van hun personeel en het gevoerde employabilitybeleid in de tijd te volgen en te benchmarken met de sectorale ontwikkelingen. Op basis van gesprekken met een aantal sleutelpersonen uit zowel de chemiesector als de detailhandel (als onderdeel van de sector handel en reparatie) wordt de Employability Portfolio Bedrijven gepresenteerd. Deze portfolio kan gezien worden als een eerste aanzet tot een employability benchmark-instrument voor individuele bedrijven. Aan de EPB wordt in dit rapport nog geen cijfermatige invulling gegeven. Wel is in de gesprekken met sleutelpersonen geïnventariseerd in hoeverre behoefte bestaat aan een benchmarkinstrument, welke informatie nodig is om het instrument invulling te geven en in hoeverre deze informatie beschikbaar is. Vervolgens wordt in paragraaf 4.3 de opzet van de in dit rapport voorgestelde Employability Portfolio's vergeleken met enkele andere initiatieven om de employability van werkenden in kaart te brengen. Ten slotte wordt in paragraaf 4.4 ingegaan op de mogelijkheden voor implementatie van de herziene Employability Portfolio's. Daarbij wordt ingegaan op de verschillende mogelijkheden voor dataverzameling die de basis kunnen vormen voor mogelijke pilotprojecten om te komen tot de voorgestelde Employability Portfolio's op sector en bedrijfsniveau. 


\section{Naar een Sectorale Employability Portfolio}

In het kader van de door overheid en sociale partners geformuleerde Employability agenda is door het Ministerie van Sociale Zaken en Werkgelegenheid en het Ministerie van Economische Zaken het voortouw genomen voor het opzetten van een instrumentarium om ontwikkelingen op het gebied van employability te volgen, te stimuleren en bij te sturen. In dat kader is door het Researchcentrum voor Onderwijs en Arbeidsmarkt een raamwerk ontwikkeld dat een dergelijke monitorring mogelijk maakt. Dit raamwerk vormt dan ook het conceptuele kader voor de verdere ontwikkeling van een Sectorale Employability Portfolio, het eerste doel van deze studie. Een dergelijke employability portfolio maakt het mogelijk om op basis van kerncijfers over verschillende relevante aspecten van de employability van werkenden $^{6}$ een vergelijking te maken tussen de employability van het personeel, de employability behoefte en de zogenaamde 'effectueringscondities' en arbeidsmarktontwikkelingen in de verschillende bedrijfssectoren.

Figuur 1

Conceptueel Model Employability Monitor

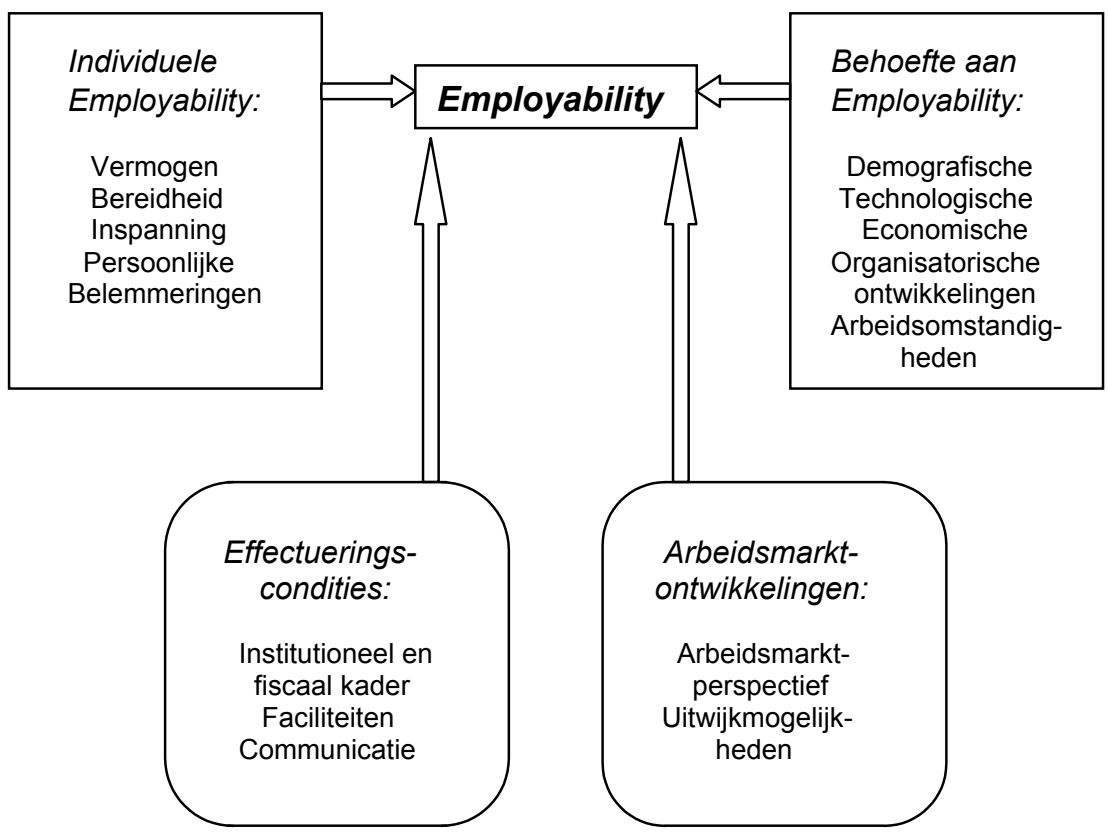

Bron: ROA

6. In A. de Grip en J. Sanders (2001), Naar een Employability Monitor, Elsevier, Den Haag/ Doetinchem, wordt ook de mogelijkheid verkend om te komen tot een Employability Monitor voor niet werkenden. 


\subsection{Het conceptuele model}

In figuur 1 is het model weergegeven dat de basis vormt voor de voorgenomen sectorale employability portfolio. Het model is in een aantal dimensies onderverdeeld. Deze dimensie-indeling is voorheen ook voor de Sectorale Employability Index ${ }^{7}$ en de Employability Monitor ${ }^{8}$ gehanteerd.

Allereerst wordt in het model gekeken naar de individuele employability van werknemers. Vervolgens naar de behoefte aan employability die op grond van diverse ontwikkelingen binnen verschillende bedrijfssectoren bestaat. Om een beeld te krijgen van de mogelijkheden die groepen werknemers hebben om aan de slag te blijven wordt vervolgens gekeken naar de arbeidsmarktperspectieven, die werknemers hebben op grond van hun opleidingsachtergrond. Ten slotte wordt gekeken naar de zogenaamde effectueringcondities. Hierbij gaat het met name om de faciliteiten die de werkgever biedt om de employability van het personeel op peil te houden of te verbeteren.

\section{Individuele employability}

De individuele employability van werknemers kan het beste worden bepaald aan de hand van een viertal centrale vragen, te weten:

wat kan de werknemer? (Vermogen)

- wat wil de werknemer? (Bereidheid)

wat doet de werknemer feitelijk? (Inspanning)

口 zijn er persoonlijke belemmeringen die het werken aan employability voor de werknemer bemoeilijken? (Persoonlijke belemmeringen)

Inzicht in wat een werknemer kan staat vanzelfsprekend aan de basis van het bepalen van de kans op het behoud van werk. Dit vermogen wordt bepaald door iemands initiële opleiding en de gevolgde post-initiële opleidingen. Daarnaast zijn specifieke competenties van werknemers van belang. Deze competenties worden niet alleen door het volgen van opleidingen, maar in belangrijke mate ook door iemands werkervaring verder ontwikkeld.

Bij het 'employability vermogen' van werkenden gaat het om hun:

1. mobiliteitsvermogen;

2. opleidingsvermogen;

3. vermogen tot een brede inzet.

Mobiliteitsvermogen is het vermogen om in een andere dan de huidige functie te gaan werken. Vooropleiding, aanvullende cursussen en trainingen en werkervaring vormen hiervoor de basis. Het is echter wel van belang de soort opleidingen die

7. Zie A. de Grip, J. van Loo en J. Sanders (1998), Employability in bedrijf: naar een Employability Index voor bedrijfssectoren, ROA-R-1998/10, Maastricht.

8. Zie A. de Grip en J. Sanders (2001), op cit.: In dit rapport wordt het hier gepresenteerde conceptuele model meer uitgebreid beschreven.

6 
iemand gevolgd heeft en de breedte c.q. eenzijdigheid van de werkervaring te bewaken. Thijssen (1989) wees erop dat een geconcentreerde ervaringsopbouw er op den duur toe kan leiden dat een werknemer vast komt te zitten in de huidige functie. Het aantal jaren dat een werknemer in één en dezelfde functie bij één en dezelfde werkgever op één en dezelfde locatie verblijft, indiceert iemands ervaringsconcentratie.

Opleidingsvermogen is het vermogen om verder te leren. Het opleidingsvermogen van werknemers is bepalend voor de mate waarin werknemers in staat zijn om te worden bij- of omgeschoold.

Het vermogen tot brede inzet is het vermogen om buiten het eigen functiegebied bepaalde taken te verrichten. Een brede inzetbaarheid geeft werknemers een breed palet van vaardigheden, waardoor zij op meerdere plaatsen binnen de organisatie of daarbuiten gemakkelijker aan de slag kunnen. Het vermogen om breed te worden ingezet wordt opgebouwd door een brede opleidingsachtergrond en een brede werkervaring.

Wat wil de werknemer?

Naast iemands vermogen is vanzelfsprekend ook de bereidheid van cruciaal belang. Hierbij zijn de volgende aandachtspunten van belang:

1. mobiliteit:

a. de bereidheid om van functie te veranderen (Functionele mobiliteit);

b. de bereidheid om op verschillende fysieke werklocaties actief te zijn (Geografische mobiliteit);

2. opleiding: de bereidheid om opleidingen en cursussen te volgen (Opleidingsbereidheid);

3. inzetbaarheid:

a. de bereidheid om verschillende taken en functies te vervullen (Kwalitatieve inzetbaarheid);

b. de bereidheid om extra werkzaamheden (overuren) te verrichten (Kwantitatieve inzetbaarheid).

Wat doet de werknemer feitelijk?

Om daadwerkelijk invulling te kunnen geven aan iemands vermogen en bereidheid, zullen werknemers ook inspanningen moeten leveren om hun employability op peil te houden. Daarbij gaat het om:

1. mobiliteit:

a. inspanningen om van functie te veranderen (Functionele mobiliteit):

b. inspanningen om op verschillende fysieke werklocaties actief te zijn (Geografische mobiliteit);

2. opleiding: cursusdeelname;

3. inzetbaarheid: 
a. mate waarin een werknemer verschillende taken en functies vervult (Kwalitatieve inzetbaarheid);

b. mate waarin een werknemer zich flexibel opstelt qua werktijden (Kwantitatieve inzetbaarheid).

Wat voor persoonlijke belemmeringen staan de werknemer in de weg?

Behalve het vermogen, de bereidheid en de inspanningen van werknemers om op de arbeidsmarkt actief te blijven moet ook aandacht worden besteed aan persoonlijke belemmeringen die iemands employability kunnen beperken. Belemmeringen die invloed kunnen hebben zijn bijvoorbeeld de gezinssituatie of het hebben van bepaalde arbeidshandicaps.

\section{Behoefte aan employability}

Bij de monitorring van de employability van werkenden is het ook belangrijk om oog te hebben voor de verschillende eisen die er op dit punt aan werkenden worden gesteld. In de ene sector zullen die groter zijn dan in de andere. De behoefte aan employability die binnen de verschillende bedrijfssectoren bestaat wordt bepaald aan de hand van de intensiteit waarmee bedrijfssectoren, organisaties en werknemers geconfronteerd worden met bepaalde (maatschappelijke) ontwikkelingen. Een vijftal zaken is hierbij van belang:

- demografische ontwikkelingen;

- economische ontwikkelingen;

- technologische ontwikkelingen;

- organisatorische ontwikkelingen;

- arbeidsomstandigheden.

\section{Demografische ontwikkelingen}

De ontgroening en vergrijzing van de beroepsbevolking vergroten het maatschappelijke belang van de employability van oudere werknemers. Bij een toenemende vergrijzing worden steeds meer van de aan het eind van de vorige eeuw sterk in omvang toegenomen uittredingswegen (o.a. VUT) voor oudere werknemers te duur. Bovendien zorgt de heersende arbeidsmarktkrapte ervoor dat het van toenemend belang is om oudere werknemers aan de slag te houden. Dat vraagt om een leeftijdsbewust employabilitybeleid.

\section{Economische ontwikkelingen}

De toenemende concurrentie op basis van kennis en knowhow vraagt om werknemers die in staat zijn in uiteenlopende situaties adequaat te handelen en zich snel nieuwe kennis en vaardigheden eigen te maken. Vooralsnog wordt bij het in beeld brengen van de economische ontwikkelingen gekeken naar de mate waarin bedrijven aangeven gevoelig te zijn voor economische schommelingen. Hoe gevoeliger de organisatie is voor deze schommelingen des te meer behoefte is er aan 
werknemers die employable zijn. Het employabilitybeleid van bedrijven zou hierop moeten zijn afgestemd.

\section{Technologische ontwikkelingen}

Technologische ontwikkelingen spelen eveneens een belangrijke rol, met name ontwikkelingen die plaatsvinden op het gebied van de informatie en communicatietechnologie (ICT) hebben belangrijke consequenties voor de kwalificatieveroudering bij werkenden. Niet alleen kan door middel van ICT de inhoud van functies sterk veranderen, zodat de kennis en vaardigheden waarover werkenden beschikken niet meer toereikend zijn voor een adequate functievervulling. Bepaalde functies kunnen zelfs helemaal verdwijnen, zodat er geen vraag meer is naar de kennis en vaardigheden van de mensen die in deze functie werkzaam waren. Werknemers en organisaties dienen continu aandacht te hebben voor manieren om kennis en vaardigheden up-to-date te houden. Dit veronderstelt een pro-actief employabilitybeleid

\section{Organisatorische ontwikkelingen}

Doordat de omgeving van organisaties voortdurend aan verandering onderhevig is moet een organisatie zich een grote mate van flexibiliteit aanmeten om op een adequate manier te kunnen reageren en anticiperen op deze veranderingen. Overigens zijn bepaalde organisatorische veranderingen sterk gerelateerd aan de mogelijkheden die technologische vernieuwingen bieden voor het leveren van maatwerk en het verbeteren van de kwaliteit van de dienstverlening. Met name organisatorische veranderingen die van invloed zijn op de personeelssamenstelling spelen een belangrijke rol bij het bepalen van de employability-behoefte. Bij organisatorische veranderingen is nagenoeg altijd sprake van een verandering in de functie en de werkzaamheden van de werknemers.

\section{Belastende arbeidsomstandigheden}

Is er sprake van een hoge fysieke en/of psychische belasting, dan wordt een werknemer eerder geconfronteerd met problemen bij het uitoefenen van diens functie. Wanneer werkenden vanwege deze belastende arbeidsomstandigheden op den duur hun werk niet meer adequaat uit kunnen oefenen, zullen zij uit moeten gaan zien naar een andere functie. Op dat moment is hun employability van groot belang, zeker ook voor de organisatie waarbinnen zij actief zijn. Goed employability- en met name ARBO beleid vermindert de negatieve gevolgen van het werken onder een hoge fysieke/ psychische belasting of stelt deze negatieve gevolgen zo lang mogelijk uit en vermindert daarmee problemen met verloop, ziekteverzuim en uitval. Wanneer werkenden desondanks op een gegeven moment toch niet langer in staat zijn hun functie uit te oefenen, is een adequaat omscholingsbeleid van groot belang.

\section{Arbeidsmarktperspectieven}

De ontwikkelingen die aan de basis staan van de behoefte aan employability die binnen een sector bestaat bepalen voor een deel ook de arbeidsmarktperspectieven van de werknemers in de verschillende bedrijfssectoren. Immers, de genoemde 
maatschappelijke ontwikkelingen zijn er in veel gevallen verantwoordelijk voor dat functies van inhoud veranderen, andere kwalificaties gevraagd worden en dat bepaalde functies zelfs geheel verdwijnen en er geheel nieuwe functies ontstaan.

De op middellange termijn te verwachten arbeidsmarktperspectieven geven een indicatie van de mate waarin werknemers erop kunnen vertrouwen dat de werkgelegenheid in het beroep, waarin zij nu actief zijn, stabiel zal blijven of zelfs zal groeien, of dat de werkgelegenheid in het beroep dat men uitoefent sterk zal afnemen. Daarbij is het ook van belang of de opleidingsachtergrond die iemand heeft over enige jaren nog toereikend zal zijn voor een adequate uitoefening van het beroep dat men nu heeft.

\section{Effectueringscondities}

Een vergelijking van de aanwezige employability van het personeel en de behoefte aan employability in een bedrijfssector levert een indicatie op van terreinen waar extra inspanningen van de kant van organisaties, werknemers of brancheorganisaties gewenst zijn. Hetzij door bepaalde faciliteiten te bieden, hetzij door bepaalde belemmeringen weg te nemen. In dit kader is het van belang een beeld te krijgen van de inspanningen die werkgevers leveren om werknemers de mogelijkheid te geven aan de individuele employability te werken. We spreken in dit verband van de effectueringscondities.

Drie hoofdaspecten zijn hierbij van belang:

- institutionele kaders: Centrale afspraken over toepassing van employabilityinstrumenten en -beleid;

- faciliteiten: Welke mogelijkheden bieden bedrijven aan werknemers om hun employability op peil te houden en/of uit te breiden? (Hoe ziet het HRM beleid eruit?);

- communicatie: In hoeverre zijn werknemers op de hoogte van de bestaande HRM faciliteiten?

\section{Institutionele kaders en faciliteiten}

In hoeverre garanderen CAO-afspraken over het employabilitybeleid werknemers dat zij hun menselijk kapitaal waardevol kunnen houden voor de arbeidsmarkt en in hoeverre wordt van deze afspraken daadwerkelijk gebruik gemaakt. Hierbij staat een aantal instrumenten centraal ${ }^{9}$, te weten:

Opleiding:

- algemene scholing (rekenen, talen, enz.);

- specifieke scholing (vaktechnisch, organisatorisch, inzetbaarheid, leeftijdsbewust en loopbaanontwikkeling);

- scholingsverlof;

9. Zie ook Arbeidsinspectie (2001), Najaarsrapportage CAO-afspraken 2001, Den Haag: Arbeidsinspectie. 
- ontwikkelingsplannen- en rekeningen (POP, BOP, POR);

- erkenning van verworven competenties (EVC).

Mobiliteit en inzetbaarheid:

- loopbaanbevordering (functioneringsgesprekken, loopbaangesprekken, mobiliteitscentrum);

- motiverend beloningsbeleid.

Arbeidsmarktgericht employabilitybeleid:

- arbeidsmarktmonitor;

- employabilityscan;

- employabilityadviseur;

- vacaturebanken;

- O\&O of A\&O-fonds;

- leeftijdsbewust personeelsbeleid;

- $\quad$ ARBO-beleid c.q. verzuimbeleid;

- arbeid en zorg.

Het is van belang te kijken naar de afspraken die worden gemaakt, maar bovenal ook naar de mate waarin de afspraken binnen organisaties daadwerkelijk leiden tot maatregelen en naar de mate waarin deze maatregelen door werknemers worden gebruikt.

\section{Communicatie}

Het is ten slotte belangrijk in kaart te brengen in hoeverre werknemers toegang hebben tot genoemde instrumenten c.q. faciliteiten. Het is bijvoorbeeld van belang dat de faciliteiten die beschikbaar zijn om de employability van de werknemers te verbeteren bekend zijn bij individuele werknemers, zodat zij weten hoe zij hierop aanspraak kunnen doen gelden. Bovendien is het voor de werkgever van belang om te weten in hoeverre het personeel tevreden is over de aanwezige faciliteiten. Informatievoorziening staat centraal voor werknemer en werkgever.

\subsection{Aandachtpunten bij de ontwikkeling van een Employability Portfolio voor sectoren en bedrijven}

Invulling van de methodiek en het conceptuele model zoals dat in paragraaf 2.1 is besproken heeft geleid tot een monitor boordevol informatie en kengetallen, die interessant zijn voor een uitgebreide benchmark. De vraag is echter in hoeverre deze grote hoeveelheid informatie regelmatig kan worden verzameld en in hoeverre de informatie (met name op bedrijfsniveau) beschikbaar en/of gewenst is.

Het eerste punt van aandacht is daarom de grote hoeveelheid informatie die in de huidige methodiek wordt verzameld. Om te komen tot een krachtig benchmarkinstrument is het nodig om kritisch te kijken naar de verschillende indicatoren en de operationalisatie van deze indicatoren binnen de huidige methodiek. 
Een tweede aandachtspunt is dat in eerdere studies op basis van de verschillende dimensies een ongewogen indexcijfer is berekend. Deze aanpak staat in het teken van de beoogde vergelijking tussen bedrijfssectoren. Voor de betrokkenen binnen een bedrijfstak is het echter ook belangrijk om precies te weten hoe de sector er op een bepaald punt voorstaat en om de ontwikkelingen in de tijd te kunnen volgen. Dit om specifieke doelen te kunnen stellen met betrekking tot de employability van de werkenden in de sector en om na te kunnen gaan welke vooruitgang een bedrijfssector op een bepaald punt heeft weten te boeken. Dit vereist een meer absolute vergelijking van gegevens in de loop van de tijd. Daarom zal hier van de indexering, die een meer overall vergelijking tussen bedrijfssectoren mogelijk maakt, worden afgestapt. In de Sectorale Employability Portfolio zal in plaats daarvan zo veel mogelijk naar absolute informatie worden gezocht.

Een derde aandachtspunt is dat de methodiek die tot nu toe is gehanteerd informatie over de effecten van een goed employabilitybeleid buiten beschouwing laat. Om te komen tot een instrument dat meer inzicht verschaft in effecten van investeringen in het employabilitybeleid is het noodzakelijk om de huidige methodiek uit te breiden met prestatie-indicatoren.

Het laatste aandachtspunt betreft de mogelijkheid voor individuele bedrijven om zich te benchmarken met de sector waarin zij opereren. Hiertoe is het noodzakelijk dat op sector- én bedrijfsniveau vergelijkbare data beschikbaar zijn.

De huidige methodiek biedt goede mogelijkheden om deze informatiebehoeften in te vullen. Op een aantal punten zal de methodiek echter moeten worden aangepast om de twee hoofddoelstellingen van dit onderzoek te kunnen realiseren.

\section{Toespitsing op kernindicatoren}

In de huidige opzet van de Employability Monitor zijn zo'n vijftig variabelen opgenomen. Het is de vraag of al deze informatie wel gewenst is, en of ze beschikbaar is, of kan worden gegenereerd. Dit laatste is natuurlijk van groot belang om te komen tot een krachtige en gebruiksvriendelijke benchmark. In dit kader is een aantal gesprekken gevoerd met sleutelfiguren binnen de detailhandel en de chemiesector. In deze gesprekken is ingegaan op de bestaande methodiek en gevraagd welke elementen daarvan de meest waardevolle informatie geven. Bovendien is geïnventariseerd in hoeverre de meest gewenste informatie beschikbaar is of kan komen. Zo wordt ervoor gezorgd dat alleen informatie wordt verzameld waaraan gebruikers van de benchmark daadwerkelijk behoefte hebben ("need to know").

Van relatieve naar absolute cijfers

Tot nu toe is voor een aantal centrale indicatoren gebruik gemaakt van relatieve cijfers. Het gebruik van dergelijke cijfers waarin de positie van één sector ten opzichte van het totaalcijfer voor alle sectoren wordt aangegeven, levert problemen op bij het bepalen van resultaten van het gevoerde employabilitybeleid. Wanneer alle sectoren bijvoorbeeld als gevolg van een goed verzuimbeleid het verzuim terug weten te brengen dan verandert er in de relatieve positie van een sector ten opzichte 
van andere sectoren niets, terwijl er in absolute zin wel degelijk sprake is van een verbetering. Om te voorkomen dat dergelijke verbeteringen onzichtbaar blijven moet de huidige methodiek worden omgezet naar een indicatorenstelsel, waarin de kernindicatoren niet worden getransformeerd tot een relatieve index. Alleen dan wordt het mogelijk de ontwikkelingen in de employability van werkenden in de tijd te volgen. Bovendien kunnen dan de vorderingen die sectoren op een bepaald terrein maken direct in beeld worden gebracht en kan beter worden bepaald in hoeverre bepaalde resultaatverbeteringen kunnen worden toegewezen aan het HRM beleid.

\section{Het meten van prestatie}

Om te kunnen indiceren in hoeverre HRM loont, is het ten slotte van belang dat zowel het indicatorenstelsel op sectorniveau als op bedrijfsniveau informatie geeft over bepaalde prestatiemaatstaven. Van Loo en De Grip geven een overzicht van mogelijke prestatieindicatoren. ${ }^{10}$ Ook deze indicatoren zijn voorgelegd aan de sectorale gesprekspartners om te inventariseren in hoeverre deze indicatoren van belang worden geacht. Bovendien is gevraagd in hoeverre bedrijven beschikken over cijfers om deze indicatoren in te vullen.

\section{Van sectorniveau naar bedrijfsniveau}

De methodiek zal dusdanig moeten worden aangepast dat het mogelijk wordt vorderingen van individuele bedrijven op het gebied van de verschillende aspecten van employability van hun personeel te kunnen volgen in de tijd en deze te benchmarken met de ontwikkelingen in de sector. Dit vereist de toespitsing op een aantal kernindicatoren, die door bedrijven kunnen worden ingevuld, zonder dat zij dit als een bureaucratische verplichting ervaren, waaraan zij zelf weinig meerwaarde hechten. Hiertoe zal een apart indicatorenstelsel voor bedrijven worden opgezet, dat echter zoveel mogelijk dezelfde kerncijfers zal bevatten als het indicatorenstelsel voor sectoren. Dit laatste stelt aan het sectorale indicatorenstelsel de aanvullende eis dat zoveel mogelijk informatie wordt verzameld die betrekking heeft op het percentage werknemers waarop een bepaald aspect van de employability betrekking heeft. Vooral voor wat betreft de informatie over de HRM faciliteiten en de informatie over de employability behoefte vraagt dit om een andere benadering dan de benadering die tot nu toe in het model is gebruikt. In de nieuwe opzet zal dan ook zoveel mogelijk worden uitgegaan van het percentage werknemers dat gebruik maakt van bepaalde faciliteiten en het percentage werknemers voor wie een goede employability als gevolg van bepaalde ontwikkelingen in en om de organisatie of de sector van groot belang is. Bijvoorbeeld door te kijken naar het percentage werknemers waarvoor geldt dat hun functie ingrijpend is veranderd als gevolg van organisatorische veranderingen.

10. J.B. van Loo en A. de Grip (2002). Loont HRM? Een literatuurverkenning. ROA-R-2002/15, Maastricht. 


\subsection{De Portfolio-methodiek}

De vier in paragraaf 2.2 besproken veranderingen in de bestaande methodiek leiden tot een nieuwe methodiek, die we de portfolio-methodiek zullen noemen. Een portfolio wordt in de Van Dale omschreven als een draagmap. Dat is ook exact wat de benchmark die we willen creëren zou moeten zijn. Een map die informatie bevat op basis waarvan men zich vrij eenvoudig en snel een compleet beeld kan vormen van de employability situatie, het gevoerde HRM beleid en de ontwikkelingen hierin binnen het bedrijf of de sector waar men actief is.

Werken volgens deze portfolio-methodiek heeft een aantal praktische voordelen die tegemoet komen aan de wensen vanuit 'het veld'. Zo is er van de kant van de MKB ondernemers geen behoefte aan langdurig onderzoek, praatsessies en dergelijke. Men wil snel inzicht in voor de bedrijfsvoering relevante informatie. Bovendien zullen niet voor elke onderneming dezelfde elementen van het employabilitybeleid even belangrijk zijn. Prioritering van deze elementen zou dus moeten gebeuren door de gebruiker van de gegevens. Presentatie van de verschillende factoren die van belang zijn voor de employability van werkenden in de vorm van een portfolio geeft de gebruiker die vrijheid.

\subsection{Sectorale Employability Portfolio (SEP)}

De schema's 2.1 tot en met 2.4 geven per dimensie een beeld van het indicatorenstelsel, dat de basis vormt voor de Sectorale (en Bedrijven) Employability Portfolio. Op grond van de in paragraaf 2.2 genoemde punten wijkt het stelsel af van de indicatorenreeks die de basis vormt voor de eerder ontwikkelde Employability Monitor.

$\checkmark$ Het aantal indicatoren is, ondanks toevoeging van een aantal 'nieuwe' indicatoren, teruggebracht. Daarbij is ervoor gezorgd dat elk aspect van de employability van werkenden wordt geoperationaliseerd met niet meer dan één variabele.

Er wordt zoveel mogelijk gebruik gemaakt van gegevens die op het niveau van de individuele werkende (kunnen) worden verzameld (d.i. percentage werknemers in bedrijf of sector dat...).

$\checkmark$ Er wordt alleen gebruik gemaakt van absolute maatstaven. Relatieve gegevens zijn vervangen of weggelaten.

$\checkmark \mathrm{Er}$ is een aantal resultaat- c.q. prestatiemaatstaven toegevoegd om te kunnen bepalen in hoeverre inspanningen in HRM op enige manier effect hebben gehad.

Behalve deze wijzigingen is ook een aantal veranderingen doorgevoerd naar aanleiding van gesprekken met sleutelfiguren in de detailhandel en de chemiesector. Op deze gesprekken en de daaruit voortgevloeide aanpassingen zal in hoofdstuk 4 nog uitgebreid worden teruggekomen, omdat in de gesprekken met name is inge- 
gaan op gebruiksmogelijkheden van de Sectorale Employability Portfolio voor de individuele bedrijvenportfolio's die in dat hoofdstuk worden besproken.

\section{Aanwezige employability}

Op een aantal punten laat schema 2.1 veranderingen zien ten opzichte van het conceptuele model voor de Employability Monitor dat in paragraaf 2.1 is beschreven.

Om de hoeveelheid indicatoren terug te brengen zijn de indicatoren initiële opleiding, vervolgopleiding, competentieniveau en opleidingsvermogen samengenomen in de indicator opleidingsniveau. Hierbij wordt eenvoudigweg gekeken naar het percentage werkenden in de sector dat tenminste een MBO opleiding heeft. Dat percentage geeft enerzijds informatie over de bij werkenden aanwezige "startkwalificatie" en anderzijds informatie over de capaciteiten om kwalificaties te verwerven (het opleidingsvermogen).

Eveneens om het totaal aantal indicatoren te beperken is ervoor gekozen nog één indicator voor de kwalitatieve inzetbaarheid op te nemen, namelijk de mate waarin werkenden zich, wanneer dat nodig is, breed inzetten. De mate waarin dat gebeurt is niet alleen een goede indicator voor de inspanningen op dit vlak, maar ook een goede voorspeller voor de mate waarin werkenden wanneer dat nodig is, breed inzetbaar zijn.

Schema 2.1

Sectorale Employability Portfolio; Aanwezige employability

\begin{tabular}{|c|c|}
\hline Aanwezige employability & Operationalisatie \\
\hline Opleidingsniveau & $\%$ werkenden met tenminste een MBO opleiding \\
\hline Werkervaring & $\begin{array}{l}\% \text { werkenden dat langer dan } 2 \text { jaar actief is op de } \\
\text { arbeidsmarkt }\end{array}$ \\
\hline Ervaringsconcentratie & $\begin{array}{l}\text { \% werkenden dat langer dan } 8 \text { jaar in de huidige functie } \\
\text { werkzaam is }\end{array}$ \\
\hline Opleidingsbereidheid & $\begin{array}{l}\% \text { werkenden dat een opleiding heeft gevolgd in de } \\
\text { afgelopen twee jaar }\end{array}$ \\
\hline Functionele mobiliteitsbereidheid & \% werkenden dat van baan wil veranderen \\
\hline Verhuisbereidheid & $\begin{array}{l}\text { \% werkenden dat bereid is te verhuizen i.v.m. een } \\
\text { nieuwe functie }\end{array}$ \\
\hline Kwalitatieve inzetbereidheid & $\begin{array}{l}\text { \% werkenden dat indien nodig taken van buiten de } \\
\text { functie op zich zou willen nemen }\end{array}$ \\
\hline Functionele mobiliteitsinspanning & $\begin{array}{l}\% \text { werkenden dat in de afgelopen twee jaar van functie } \\
\text { is veranderd }\end{array}$ \\
\hline Kwalitatieve inzet & $\begin{array}{l}\text { \% werkenden dat vaak taken op zich neemt van buiten } \\
\text { de eigen functie }\end{array}$ \\
\hline Kwantitatieve inzet & $\%$ werkenden met onregelmatige werktijden \\
\hline Gezinssituatie belemmerend & $\begin{array}{l}\% \text { werkenden dat gehuwd is en thuiswonende kinderen } \\
\text { heeft }\end{array}$ \\
\hline Gezondheid belemmerend & $\begin{array}{l}\text { \% werkenden dat zich als gevolg van de gezondheid } \\
\text { belemmerd voelt bij het uitoefenen van het werk }\end{array}$ \\
\hline
\end{tabular}


Ook is er, om het aantal indicatoren terug te brengen, nog maar één indicator voor de kwantitatieve inzetbaarheid. Gekeken wordt daarbij naar de mate waarin werkenden op onregelmatige werktijden werken. Dit is tevens een goede voorspeller voor de mate waarin werkenden in staat zijn om, indien nodig, op onregelmatige werktijden te werken.

De indicatoren die betrekking hebben op de geografische mobiliteit zijn ten slotte ook samengenomen in één indicator voor de verhuisbereidheid. Gekeken zou daarbij moeten worden naaar het percentage werkenden dat bereid is te verhuizen in verband met een nieuwe functie.

\section{Behoefte aan employability en arbeidsmarktperspectieven}

Schema 2.2 laat zien dat er ook bij de indicatoren voor de 'Behoefte aan employability' het een en ander verandert. De behoefte aan employability die voortkomt uit economische vernieuwingen wordt in beeld gebracht door te kijken naar de mate waarin bedrijven gevoelig zijn voor schommelingen in de economische conjunctuur. Deze gevoeligheid wordt bepaald op een driepuntsschaal (ja,in sterke mate; ja, enigszins; nee, niet gevoelig). In de Sectorale Employability Portfolio wordt vervolgens gekeken naar de gemiddelde gevoeligheid van bedrijven in een sector. Hiervoor is gekozen omdat het in de oorspronkelijke opzet, waarbij het percentage bedrijven in een sector dat aangeeft gevoelig te zijn voor schommelingen in de economische conjunctuur als operationalisatie was gekozen onmogelijk is om individuele bedrijvenportfolio's in te richten, die een vergelijking met de sectorportfolio's toestaan.

Schema 2.2

Sectorale Employability Portfolio Ontwikkeling; Behoefte aan employability en arbeidsmarktperspectieven

\begin{tabular}{|l|l|}
\hline Behoefte aan employability & Operationalisatie \\
\hline Demografische ontwikkelingen & Ratio van ouderen (>=50) en jongeren (<=30 jaar) \\
\hline Economische ontwikkelingen & $\begin{array}{l}\text { Mate waarin bedrijven gevoelig zijn voor conjuncturele } \\
\text { schommelingen }\end{array}$ \\
\hline Technologische vernieuwingen & $\begin{array}{l}\text { \% werkenden dat met een nieuwe techniek/ technologie } \\
\text { is gaan werken }\end{array}$ \\
\hline Organisatorische veranderingen & $\%$ werkenden dat wordt getroffen door reorganisaties \\
\hline Fysieke belasting & $\begin{array}{l}\text { \% werkenden dat a.g.v. lichamelijke belasting het werk } \\
\text { verzuimt }\end{array}$ \\
\hline Psychische belasting & $\begin{array}{l}\text { \% werkenden dat a.g.v. werkdruk het werk verzuimt } \\
\text { Conflicten }\end{array}$ \\
\hline \multicolumn{2}{|l}{ collega's het werk verzuimt } \\
\hline Arbeidsmarktperspectieven & $\begin{array}{l}\text { \% werkenden met (zeer) goede } \\
\text { arbeidsmarktperspectieven op basis van hun } \\
\text { opleidingsachtergrond }\end{array}$ \\
\hline (Zeer) goede \\
arbeidsmarktperspectieven
\end{tabular}


Soortgelijke argumenten staan aan de basis van de keuze om de behoefte aan employability die voortkomt uit technologische vernieuwingen of organisatorische veranderingen in beeld te brengen door te kijken naar respectievelijk het percentage werkenden dat met een nieuwe techniek is gaan werken en het percentage werkenden dat betrokken is bij een reorganisatie. Dat betekent dat niet meer gekeken wordt naar het percentage bedrijven dat een nieuwe techniek of nieuwe technologie heeft ingevoerd en het percentage bedrijven dat een reorganisatie heeft doorgevoerd. Beide aanpassingen zijn bovendien ingegeven door de gedachte dat er behoefte ontstaat aan employability daar waar de functie van een werkende feitelijk verandert als gevolg van technologische vernieuwingen of organisatorische veranderingen en niet zozeer daar waar alleen nieuwe technieken of reorganisaties worden doorgevoerd.

Bij het bepalen van de mate waarin de fysieke en psychische belasting door het werk de behoefte aan employability verhoogt wordt gekeken naar het percentage werkenden dat het werk heeft verzuimd als gevolg van lichamelijke belasting of een hoge werkdruk. In de eerdere Employability Monitor werd gekeken naar het percentage werkenden dat onder fysiek of psychisch belastende omstandigheden werkt. De nieuwe operationalisatie meet echter directer de behoefte aan employability, omdat bij verzuim vanwege belasting reeds sprake is van een situatie waarin werkenden zich moeten gaan herbezinnen op de functie die zij bekleden en de manier waarop zij deze functie invullen. Op dat moment wordt een beroep gedaan op de aanwezige employability.

Ten slotte is een nieuwe indicator toegevoegd. Dit op uitdrukkelijk verzoek van sleutelfiguren uit zowel de chemie als de detailhandel het gaat hierbij om het percentage werkenden dat verzuimt vanwege conflicten met leidinggevenden of collega's. Deze vorm van verzuim valt niet onder de beide andere vormen, maar neemt wel aan belang toe. Uit onderzoek naar de kosten van pesten blijkt bijvoorbeeld dat pesten op het werk de Nederlandse maatschappij en het Nederlandse bedrijfsleven jaarlijks zo'n $€ 360$ miljoen zou kunnen kosten. ${ }^{11}$ Wanneer bedrijven relatief veel te maken hebben met verzuim vanwege conflicten ontstaat er een situatie waarin werkenden niet in hun huidige functie verder kunnen. Op dat moment is er sprake van behoefte aan employability van de werkende.

De dimensie arbeidsmarktontwikkeling blijft in het nieuwe indicatorenstelsel ongewijzigd.

\section{HRM faciliteiten}

Schema 2.3 laat de indicatoren van de Sectorale Employability Portfolio zien die betrekking hebben op de (vroegere) dimensie 'effectueringscondities'. Een aantal belangrijke veranderingen verdient daarbij nadere toelichting.

11. Zie B. van der Meer (1997). Pesten op het werk. Assen: Van Gorcum. 
Allereerst wordt in het nieuwe indicatorenstelsel geen aandacht meer geschonken aan institutionele en fiscale kaders. Dit omdat voor alle sectoren dezelfde fiscale kaders gelden en op die gronden benchmarking dus niet zinvol is. Bovendien zegt de informatie over het al dan niet maken van centrale afspraken maar weinig over de feitelijke inspanningen van bedrijven om het werken aan de employability van hun personeel te faciliteren.

Ook communicatie verdwijnt als centraal aspect uit het indicatorenstelsel. Enerzijds is daarvoor gekozen omdat de gewenste informatie niet voorhanden is. Anderzijds wordt de mate waarin werkenden bekend zijn met faciliteiten binnen het bedrijf waar zij werken al indirect bepaald door niet alleen aandacht te besteden aan de beschikbaarheid van faciliteiten, maar ook te kijken naar het gebruik ervan door werkenden. Communicatie verdwijnt dus ook omdat het totaal aantal indicatoren beperkt moet blijven tot een beperkt aantal kernindicatoren.

Een voordeel van de toespitsing op de door bedrijven geboden faciliteiten die de werkende ter beschikking staan is overigens ook dat de wat moeizame term 'effectueringscondities' vervangen kan worden door de meer gangbare term 'HRM faciliteiten'.

Om te beoordelen in hoeverre het employabilitybeleid van een bedrijf of sector effectief is, is het allereerst noodzakelijk om te kijken naar de beschikbaarheid van HRM faciliteiten. In het indicatorenstelsel dat de basis vormt voor de Sectorale Employability Portfolio zijn dan ook indicatoren opgenomen die een inventarisatie mogelijk maken van het percentage bedrijven in een sector dat bepaalde HRM faciliteiten aanbiedt.

De HRM faciliteiten die zijn opgenomen in het indicatorenstelsel zijn de volgende:

- opleidingsfaciliteiten ;

- kinderopvang;

- afstemming zorg en arbeid;

- functieroulatie;

- leeftijdsbewust personeelsbeleid;

- ARBO beleid;

- verzuimbegeleiding;

- persoonlijke Ontwikkelingsplannen (POP);

- functioneringgesprekken;

- ondersteuning leidinggevenden.

Om te bepalen in welke mate opleidingsfaciliteiten en kinderopvang beschikbaar zijn binnen bedrijven en instellingen wordt in het indicatorenstelsel achtereenvolgens gekeken naar het percentage bedrijven dat werkt met een opleidingsbudget en het percentage bedrijven dat faciliteiten voor kinderopvang biedt. Daarnaast wordt, mede vanwege het argument dat individuele bedrijven zich zouden moeten kunnen spiegelen met het totaalbeeld binnen de eigen sector, gekeken naar het gebruik van deze faciliteiten: het percentage werkenden dat op kosten van de werkgever aan 
scholing heeft deelgenomen en het percentage werkenden dat gebruik maakt van kinderopvang.

Het al dan niet hebben van een eigen opleidingscentrum komt als indicator te vervallen. Een belangrijke overweging bij de beslissing deze indicator te laten vervallen is dat dergelijke centra feitelijk alleen in grote bedrijven worden ingericht en zelden in het MKB.

De indicator zorg en arbeid is toegevoegd aan de portfolio. Dit element is van belang, omdat het bieden van voldoende mogelijkheden tot het combineren van arbeid en zorg ervoor zorgt dat werkenden de ruimte hebben om naast hun zorgtaken ook op een individuele manier vorm te kunnen geven aan hun loopbaan. Bovendien zorgt de aanwezigheid van voldoende combinatiemogelijkheden er voor dat minder werknemers uitstromen om zorgtaken te kunnen verrichten. Op die manier zijn werkenden beter in staat hun kwalificaties te behouden, zodat zij hun waarde voor de arbeidsmarkt niet, of minder snel, verliezen.

Schema 2.3

Sectorale Employability Portfolio Ontwikkeling; HRM faciliteiten

\begin{tabular}{|c|c|c|}
\hline \multirow{2}{*}{ HRM faciliteiten } & \multicolumn{2}{|l|}{ Operationalisatie } \\
\hline & Beschikbaarheid & Gebruik \\
\hline Kinderopvang & $\begin{array}{l}\% \text { bedrijven dat faciliteiten } \\
\text { voor kinderopvang biedt }\end{array}$ & $\begin{array}{l}\text { \% werkenden dat gebruik maakt van } \\
\text { kinderopvang }\end{array}$ \\
\hline Opleiding & $\begin{array}{l}\% \text { bedrijven met } \\
\text { opleidingsbudget }\end{array}$ & $\begin{array}{l}\% \text { werkenden dat een door de } \\
\text { werkgever betaalde opleiding heeft } \\
\text { gevolgd }\end{array}$ \\
\hline Zorg en arbeid & \multicolumn{2}{|c|}{$\%$ werkenden dat werktijden goed kan afstemmen op de thuissituatie } \\
\hline Functieroulatie & \multicolumn{2}{|c|}{$\%$ bedrijven dat beleid voert op het gebied van taak of functieroulatie } \\
\hline Ouderenbeleid & \multicolumn{2}{|c|}{$\%$ bedrijven dat een ouderenbeleid heeft uitgewerkt } \\
\hline ARBO/verzuim & \multicolumn{2}{|c|}{$\%$ bedrijven dat een ARBO/verzuimplan heeft uitgewerkt } \\
\hline Reïntegratie & \multicolumn{2}{|c|}{$\%$ bedrijven dat een reïntegratieprotocol heeft uitgewerkt } \\
\hline & \multicolumn{2}{|l|}{ Kwaliteit van de HRM faciliteiten } \\
\hline POP & \multicolumn{2}{|c|}{ \% werkenden waarvoor POP's zijn opgesteld } \\
\hline Functioneringsgesprek & \multicolumn{2}{|c|}{$\begin{array}{l}\text { \% werkenden waarmee jaarlijks functioneringsgesprekken worden } \\
\text { gevoerd }\end{array}$} \\
\hline Ondersteuning & \multicolumn{2}{|c|}{$\%$ werkenden met voldoende ondersteuning van de leidinggevende } \\
\hline
\end{tabular}

Ten slotte is van belang te bepalen in hoeverre bedrijven en instellingen de kwaliteit van het gebruik van de beschikbaar gestelde faciliteiten bewaken door bijvoorbeeld met de werkenden afspraken te maken over het gebruik van faciliteiten en dat gebruik ook te evalueren. Organisaties die structureel aandacht besteden aan de selectie van goede trainingsprogramma's (mede op basis van de wensen van werkenden) halen bijvoorbeeld aanzienlijk meer rendement uit trainingen. ${ }^{12} \mathrm{Om}$ te bepalen in hoeverre er structurele aandacht is voor de bewaking van de kwaliteit van

12. Zie J.M.P. de Kok (2000). The impact of firm-provided training on production: testing for firm-size effects, Tinbergen Instituut, Discussion paper 00-073/3, Amsterdam/Rotterdam. 
het HRM beleid zal in de portfolio's worden gekeken naar de mate waarin instrumenten als het Persoonlijk Ontwikkelingsplan $(P O P)^{13}$ en functioneringsgesprekken in de bedrijfsvoering zijn geïntegreerd. Ook zal worden gekeken naar de mate waarin werkenden zich in hun ontwikkeling binnen het bedrijf voldoende gesteund voelen door hun leidinggevende. Deze drie indicatoren vervangen de indicator mobiliteitsondersteunende faciliteiten

Elementen als het hebben van een leeftijdsbewust personeelsbeleid, het hebben van een verzuim c.q. reïntegratieprotocol en een Arboplan blijven in het indicatorenstelsel gehandhaafd.

\section{Prestatiemaatstaven}

In schema 2.4 worden ten slotte de prestatiemaatstaven vermeld die in de Sectorale Employability Portfolio zijn opgenomen. De indicatoren die zijn opgenomen zijn mede geselecteerd op basis van de resultaten van literatuuronderzoek. ${ }^{14}$

Werknemerstevredenheid staat aan de basis van een optimale organisatieprestatie. Tevreden werknemers verzuimen immers minder, vertrekken minder snel, produceren meer, zijn gemotiveerder en hebben meestal wat meer over 'voor de zaak'. Eén van de centrale doelstellingen van het employabilitybeleid van organisaties is dan ook het bevorderen van deze tevredenheid. Het investeren in een goed HRM beleid zou hier een belangrijke bijdrage aan kunnen leveren.

De werknemerstevredenheid zal worden bepaald door te kijken naar het percentage werkenden dat aangeeft tevreden tot zeer tevreden te zijn met de huidige functie.

Bij verzuim gaat het om het percentage werkenden dat in een bepaald jaar het werk heeft verzuimd. Het verzuimpercentage geeft vrij direct inzicht in de mate waarin bijvoorbeeld verzuimbegeleiding en ARBO beleid van een bedrijf succesvol zijn. Omdat niet alle verzuim echter is terug te voeren op belastende arbeidsomstandigheden en er ook sprake kan zijn van verzuim vanwege bijvoorbeeld een slechte werksfeer, conflicten of een slecht bij iemands competenties aansluitende werkinhoud, kan het ziekteverzuim in een breder perspectief worden beschouwd als een indicatie voor het succes van het HRM beleid van een bedrijf of instelling.

Personeelsverloop kan worden geïndiceerd door het percentage werkenden dat het bedrijf of de instelling in een bepaald jaar verlaat. Personeelsverloop is een belangrijke indicator voor het succes van HRM-beleid binnen bedrijven en instellingen. Het is echter zeker niet zo dat hoe lager het verloop des te succesvoller het beleid. Een zekere mate van personeelsdoorstroom is zelfs wenselijk om de organi-

13. Een POP is een voor de individuele werknemer geformuleerd ontwikkelings- of leerplan dat jaarlijks wordt bekeken en besproken met de direct leidinggevende. Zie: Buchel, Y. (2002). Persoonlijke ontwikkelingsplannen in de praktijk. Gids voor personeelsmanagement. Vol. 81, 1, pp.51-53.

14. J.B. van Loo en A. de Grip (2002). Loont HRM? Een literatuurverkenning, ROA-R-2002/15, Maastricht. 
satie met enige regelmaat te voorzien van nieuw menselijk kapitaal en bijvoorbeeld vergrijzing van het personeelsbestand te voorkomen. Een erg hoog verloop is echter eveneens onwenselijk, omdat een hoog verloop vraagt om flinke investeringen in werving, selectie en ontwikkeling van nieuwe arbeidskrachten. Bovendien is er in dat geval meestal ook sprake van productiviteitsverlies omdat nieuwe arbeidskrachten zelden direct eenzelfde productiviteitsniveau hebben als de vertrekkende arbeidskrachten.

Schema 2.4

Sectorale Employability Portfolio Ontwikkeling; Prestatiemaatstaven

\begin{tabular}{|l|l|}
\hline Prestatiemaatstaven & Operationalisatie \\
\hline Werknemerstevredenheid & $\%$ werkenden dat (zeer) tevreden is met de huidige functie \\
\hline Verzuim & $\%$ werkenden dat werk verzuimt, exclusief zwangerschap \\
\hline Personeelsverloop & $\%$ werkenden dat de organisatie heeft verlaten \\
\hline Wervingskracht & $\%$ moeilijk vervulbare vacatures op aantal werkenden \\
\hline Productiviteit & Omzet per werkende \\
\hline Resultaat & Resultaat voor belastingheffing per werkende \\
\hline
\end{tabular}

Omdat niet gemakkelijk kan worden vastgesteld wat het gewenste personeelsverloop van een organisatie is, is ervoor gekozen in de portfolio eenvoudigweg het feitelijke personeelsverloop op te nemen. Het is vervolgens aan de gebruiker om te beoordelen in hoeverre het verloop te hoog is of niet. Benchmarking van het personeelsverloop binnen de sector en benchmarking van het eigen verloop in de tijd kan het inzicht in het wenselijke personeelsverloop vergroten.

Employability beleid moet er onder andere voor zorgen dat bedrijven minder moeite hebben met het opvullen van vacatures. Enerzijds doordat het aanwezige potentieel optimaal wordt benut en ontwikkeld, anderzijds doordat de externe wervingspositie van bedrijven, waarvan bekend is dat er sprake is van goed employabilitybeleid, waarschijnlijk beter is. Om de wervingskracht van bedrijven te beoordelen kan worden gekeken naar het percentage moeilijk vervulbare vacatures op het totaal aantal vacatures.

De arbeidsproductiviteit van werkenden in organisaties is een belangrijke indicator voor de performance van organisaties omdat hier sprake is van een maatstaf voor de effectiviteit waarmee werkenden met de door de organisatie ter beschikking gestelde kapitaalgoederen output leveren. Van een effectief employabilitybeleid mag verwacht worden dat het leidt tot een hogere arbeidsproductiviteit van de werkenden in een bedrijf. ${ }^{15}$

De arbeidsproductiviteit van werkenden zal geïndiceerd kunnen worden door de gemiddelde omzet per werkende. Dat betekent dat de totale jaaromzet van een bedrijf wordt gedeeld door het totaal aantal werkenden dat voor deze omzet heeft gezorgd. Vanzelfsprekend zou de toegevoegde waarde van een organisatie een

15. Zie J.B. van Loo en A. de Grip (2003). Loont het investeren in het personeel. ROA-R2003/1, Maastricht. 
betere maatstaf zijn voor de productiviteit. Nadeel van deze maatstaf is echter dat het vaak een aanzienlijke inspanning vergt deze te berekenen. Aangenomen mag worden dat binnen een bepaalde sector de gemiddelde omzet per werkende een goede indicator is voor de productiviteit. Voor een vergelijking tussen verschillende bedrijfssectoren is deze indicator echter minder geschikt.

Om ten slotte een beeld te krijgen van het feitelijke bedrijfsresultaat kijken we naar het resultaat voor belastingheffing dat bedrijven boeken, gedeeld door het totaal aantal werkenden. Deze informatie is gemakkelijk beschikbaar te maken. Nadeel van deze maatstaf is overigens wel dat het bedrijfsresultaat door erg veel factoren wordt beïnvloed. 


\section{Employability Portfolio Chemie en Handel en reparatie}

In dit hoofdstuk wordt op basis van het in de schema's 2.1 tot en met 2.4 gepresenteerde indicatorenstelsel een (proef) invulling gegeven aan de Sectorale Employability Portfolio voor de sectoren chemie (paragraaf 3.2) en handel en reparatie (paragraaf 3.3). Dit om een goed idee te krijgen van het eindproduct van de opzet, zoals we die in hoofdstuk 2 hebben besproken. Allereerst wordt echter in paragraaf 3.1 kort ingegaan op de voor deze eerste invulling gebruikte databronnen.

\subsection{Databronnen}

Bij de invulling van de Sectorale Employability Portfolio voor de sectoren Chemie en Handel en Reparatie is gebruik gemaakt van de volgende databronnen:

- arbeidsaanbodpanel (OSA);

- arbeidsvraagpanel (OSA);

- enquête Beroepsbevolking/ EBB (CBS);

- bedrijfsopleidingenenquête/ BOE (CBS);

- permanent Onderzoek Leefsituatie/ POLS (CBS);

- de Arbeidsmarkt naar Opleiding en Beroep/ ANOB (ROA).

Arbeidsaanbodpanel (OSA)

Het Arbeidsaanbodpanel van de Organisatie voor Strategisch Arbeidsmarktonderzoek (OSA) is een meetinstrument waarmee tweejaarlijks gegevens worden verzameld over de (potentiële) beroepsbevolking in Nederland. Het instrument richt zich op personen in de leeftijdscategorie 16 tot 65 jaar die geen dagonderwijs volgen. Bij de eerste invulling van de portfolio's is gebruik gemaakt van de peiling van 2000 (de negende 'golf').

\section{Arbeidsvraagpanel (OSA)}

Ook het Arbeidsvraagpanel van de OSA is een meetinstrument waarmee tweejaarlijks gegevens kunnen worden verzameld. In het arbeidsvraagpanel gaat het echter om gegevens over bedrijven en instellingen in Nederland. De onderzoekspopulatie van dit onderzoek wordt gevormd door arbeidsorganisaties met minimaal 5 werknemers. De informatie wordt zowel schriftelijk als mondeling verzameld. Bij de eerste invulling van de Sectorale Employability Portfolio's is gebruik gemaakt van informatie uit de peiling van 1999 (de zesde 'golf').

\section{Enquête Beroepsbevolking}

De Enquête Beroepsbevolking (EBB) van het Centraal Bureau voor de Statistiek (CBS) is een continu enquêteonderzoek dat sinds 1987 wordt uitgevoerd onder personen van 15 jaar of ouder die in Nederland wonen. Bij de eerste invulling van de portfolio's is gebruik gemaakt van gegevens die betrekking hebben op de jaren 1999- 
2000, met uitzondering van de indicator gezinssituatie belemmerend. Hiervoor is informatie gebruikt, die betrekking heeft op 1998-1999.

\section{Bedrijfsopleidingenenquête}

De Bedrijfsopleidingenenquête van het CBS heeft als centrale doelstelling het verzamelen van gegevens over de omvang, samenstelling en kenmerken van opleidingsactiviteiten die particuliere bedrijven ondernemen ten behoeve van hun werknemers. Vooralsnog is de enquête drie keer gehouden, in 1989, 1993 en in 1999. Voor de eerste invulling van de portfolio's wordt gebruik gemaakt van de gegevens uit 1999.

\section{Permanent Onderzoek Leefsituatie}

Het Permanent Onderzoek Leefsituatie is een survey onder personen, dat tot doel heeft op permanente basis hoogwaardige en coherente informatie te verzamelen over de leefsituatie van de Nederlandse bevolking. Opdrachtgever is het CBS en het onderzoek wordt in haar huidige vorm sinds 1997 jaarlijks uitgevoerd. Bij de eerste invulling van de sectorale portfolio's wordt gebruik gemaakt van informatie uit het AROM-blok (Arbeidsomstandigheden) in de module GEZO (Gezondheid en Arbeid) van de POLS enquête van 1999.

\section{De Arbeidsmarkt naar Opleiding en Beroep}

De Arbeidsmarkt naar Opleiding en Beroep (ANOB) is een tweejaarlijkse overzichtsrapportage van het Researchcentrum voor Onderwijs en Arbeidsmarkt (ROA) in het kader van het Project Onderwijs-Arbeidsmarkt (POA). De ANOB geeft inzicht in de huidige en toekomstige arbeidsmarktpositie van de verschillende beroeps- en opleidingscategorieën. In de Sectorale Employability Portfolio's wordt gebruik gemaakt van de informatie over het percentage werkenden dat goede tot zeer goede arbeidsmarktperspectieven heeft, gezien de opleidingsachtergrond. Bij de eerste invulling van de portfolio's is gebruik gemaakt van informatie uit het in 1999 gepubliceerde rapport 'De Arbeidsmarkt naar Opleiding en Beroep tot 2004'.

In schema 3.1 wordt per indicator aangegeven welke databron is gebruikt bij de invulling van de Sectorale Employability Portfolio's.

Schema 3.1

Gebruikte databronnen Sectorale Employability Portfolio's, 2002

\begin{tabular}{|l|l|l|l|l|l|l|}
\hline & $\begin{array}{l}\text { OSA } \\
\text { Aanbod }\end{array}$ & $\begin{array}{l}\text { OSA } \\
\text { Vraag }\end{array}$ & $\begin{array}{l}\text { CBS } \\
\text { EBB }\end{array}$ & $\begin{array}{l}\text { CBS } \\
\text { BOE }\end{array}$ & $\begin{array}{l}\text { CBS } \\
\text { POLS }\end{array}$ & $\begin{array}{l}\text { ROA } \\
\text { ANOB }\end{array}$ \\
\hline Aanwezige employability & & & & & & \\
\hline Opleidingsniveau & & & & & & \\
\hline Werkervaring & & & & & \\
\hline Ervaringsconcentratie & & & & & \\
\hline Opleidingsbereidheid & & & & & \\
\hline Functionele mobiliteitsbereidheid & & & & & & \\
\hline
\end{tabular}


Schema 3.1 (vervolg)

Gebruikte databronnen Sectorale Employability Portfolio's, 2002

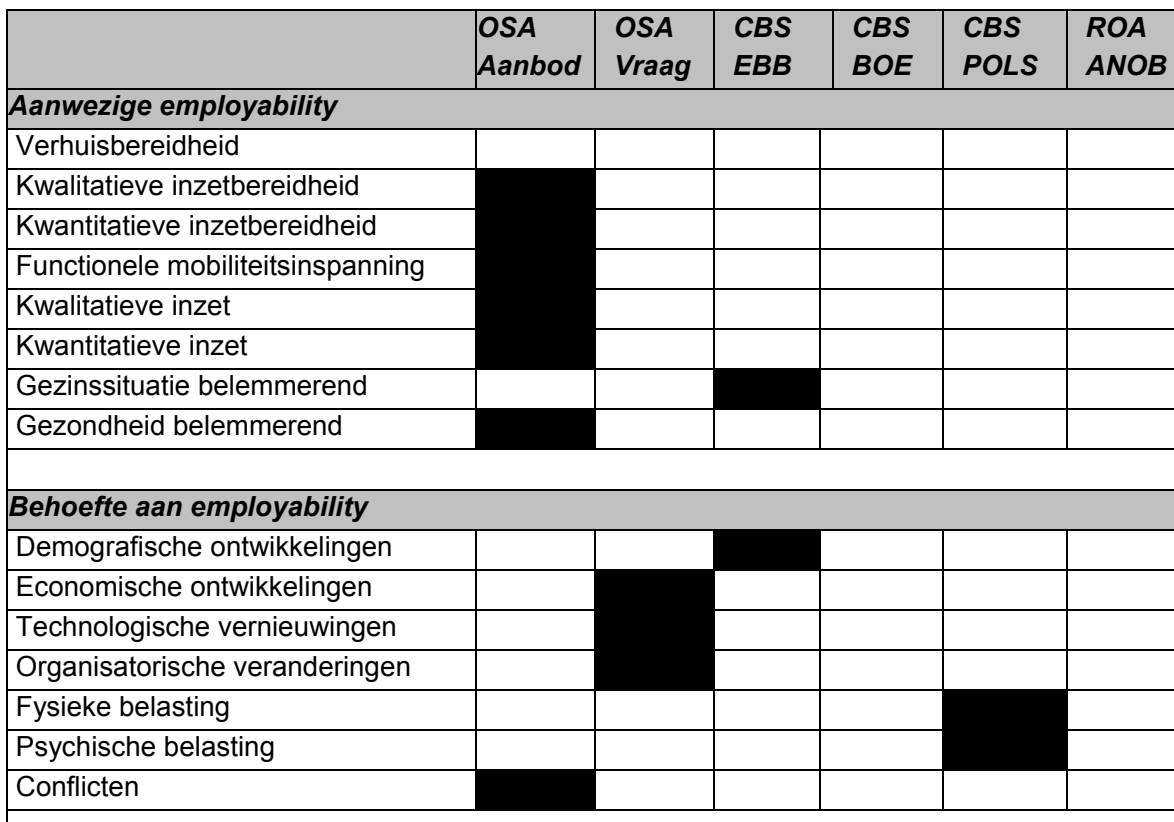

\section{Arbeidsmarktontwikkeling

\begin{tabular}{|l|l|l|l|l|}
\hline (Zeer) goede arbeidsmarktperspectieven & & & & \\
\hline
\end{tabular}

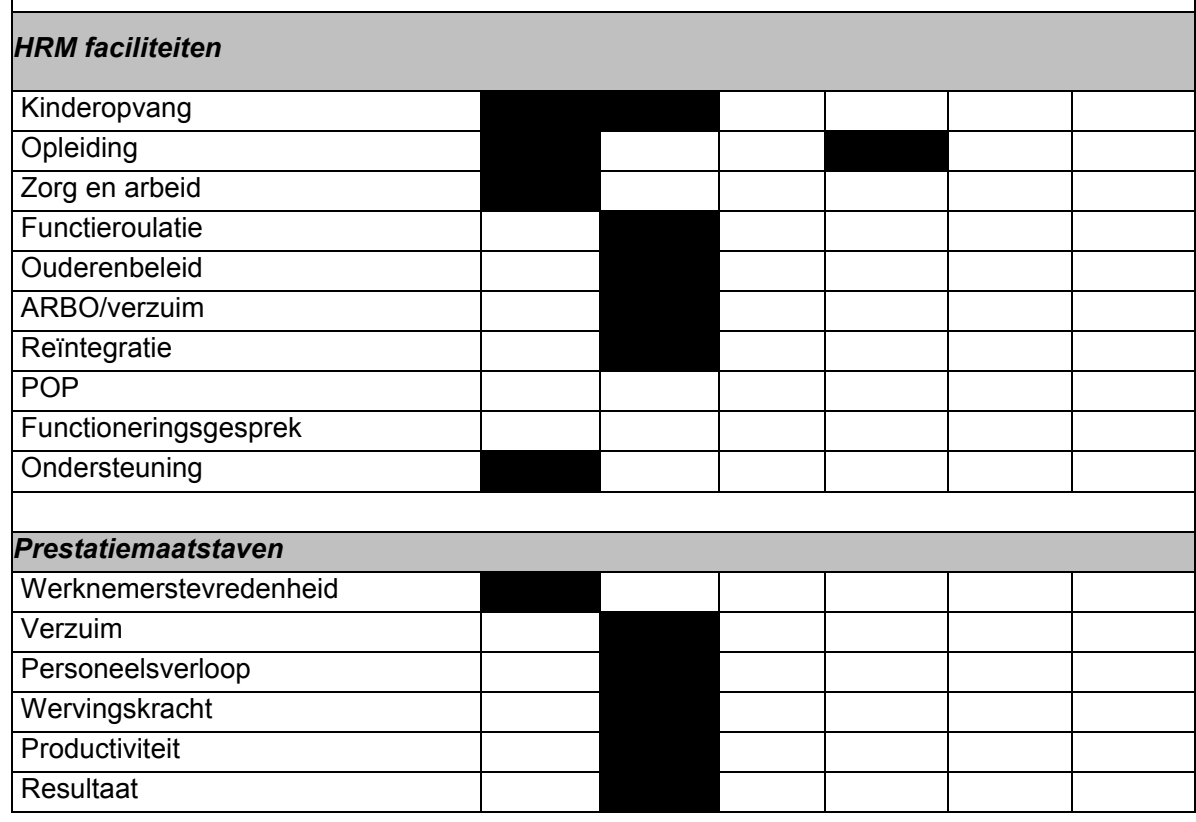

= gebruik van databron 


\subsection{Lacunes in de op dit moment beschikbare informatie}

Voor een aantal indicatoren is vooralsnog in de beschikbare databronnen geen actuele informatie beschikbaar, dit zijn:

- verhuisbereidheid (aanwezige employability);

- functionele mobiliteitsinspanning (aanwezige employability);

- $\quad$ POP (HRM faciliteiten);

- functioneringsgesprek (HRM faciliteiten);

- productiviteit (Prestatiemaatstaven);

- resultaat (Prestatiemaatstaven).

Voor een optimale bruikbaarheid van de portfolio is het vanzelfsprekend zeer gewenst dat informatie over genoemde indicatoren in de toekomst beschikbaar komt.

Bovendien is het van belang dat de informatie die in deze portfolio is opgenomen met enige regelmaat kan worden geactualiseerd, zodat een goed beeld kan ontstaan van de ontwikkelingen binnen sectoren op het gebied van employabilitybeleid en de resultaten die ermee worden geboekt. Voor de hand ligt een tweejaarlijkse actualisering. Het grootste deel van de data die voor de invulling van de sectorale portfolio's nodig zijn (OSA vraag- en aanbodpanel, ROA ANOB) wordt immers tweejaarlijks verzameld.

De bedrijfsopleidingenenquête is vooralsnog onregelmatig uitgevoerd, in 1989, 1993 en in 1999. Vooralsnog kan de indicator opleiding (HRM faciliteiten) derhalve niet tweejaarlijks worden geactualiseerd. Het toenemende belang van informatie over het onderhoud van het menselijk kapitaal in organisaties en instellingen pleit voor het opvoeren van de frequentie waarop de bedrijfsopleidingenenquête wordt gehouden. In elk geval zou de informatie over de beschikbaarheid van opleidingsfaciliteiten (opleidingsbudgetten) in organisaties en instellingen tweejaarlijks beschikbaar moeten komen om de sectorale employability portfolio tijdig en volledig te kunnen actualiseren. Dit zou kunnen door bijvoorbeeld een vraag hieromtrent op te nemen in de vragenlijst van het OSA Vraagpanel.

\subsection{De Employability Portfolio voor de sectoren Chemie en Handel en Reparatie}

In de Sectorale Employability Portfolio's wordt, zoals gezegd, weergegeven hoe de sector ervoor staat qua employability. Om de situatie van de sector op elke individuele indicator te kunnen benchmarken is behalve informatie over de sector zelf ook de top-score (kolom 2) en de bottom-score (kolom 3) weergegeven. Hierbij gaat het om respectievelijk de score van de sector die het gunstigst scoort (topscore) en de score van de sector die het minst gunstig scoort (bottom-score) op een bepaalde indicator. $^{16}$

16. Dit betekent overigens dat de topscore niet per definitie ook de hoogste score is. Wanneer bijvoorbeeld naar ziekteverzuim wordt gekeken is de topscore vanzelfsprekend de laagste score en de bottom-score de hoogste. 
Vervolgens is, door indicatoren in de portfolio's vetgedrukt te maken, aangegeven voor welke indicatoren de sector, waarvoor de portfolio is ingevuld, de topscore scoort. Door indicatoren te onderstrepen is bovendien aangegeven op welke indicatoren een sector de bottom-score heeft. Zo is in één oogopslag te zien hoe de sector er op de afzonderlijke indicatoren voor staat. Door vervolgens cijfers van opeenvolgende jaren op te nemen kan ook de ontwikkeling van een bepaalde sector gemakkelijk zichtbaar worden gemaakt. In deze eerste invulling is deze stap echter nog niet gezet.

\section{Chemie}

In tabel 3.1 is een eerste invulling gegeven aan de Sectorale Employability Portfolio voor de sector Chemie.

Tabel 3.1

Employability Portfolio voor de sector Chemie, eerste invulling

\begin{tabular}{|c|c|c|c|}
\hline & Top & Bottom & Chemie \\
\hline \multicolumn{4}{|c|}{ Aanwezige employability (top = meest employable) } \\
\hline Opleidingsniveau MBO-plus & 88 & 55 & 71 \\
\hline Werkervaring & 100 & 92 & 95 \\
\hline Ervaringsconcentratie & 17 & 39 & 35 \\
\hline Functionele mobiliteitsbereidheid & 19 & 6 & 11 \\
\hline Verhuisbereidheid & $\mathrm{nb}$ & $\mathrm{nb}$ & $\mathrm{nb}$ \\
\hline Opleidingsbereidheid & 66 & 43 & 59 \\
\hline Kwalitatieve inzetbereidheid & 85 & 65 & 74 \\
\hline Functionele mobiliteitsinspanning & $\mathrm{nb}$ & $\mathrm{nb}$ & $\mathrm{nb}$ \\
\hline Opleidingsinspanning & 12 & 2 & 9 \\
\hline Kwalitatieve inzet & 21 & 5 & 15 \\
\hline Kwantitatieve inzet & 48 & 4 & 20 \\
\hline Gezinssituatie belemmerend & 34 & 44 & 43 \\
\hline Gezondheid belemmerend & 9 & 25 & 15 \\
\hline \multicolumn{4}{|c|}{ Employability behoefte (top= minste behoefte) } \\
\hline Demografische ontwikkelingen & 0,4 & 2,3 & 0,8 \\
\hline Economische ontwikkelingen & 1,4 & 2,3 & 2,2 \\
\hline Technologische vernieuwingen & 4 & 23 & 7 \\
\hline Organisatorische veranderingen & 5 & 19 & 10 \\
\hline Fysieke belasting & 4 & 14 & 10 \\
\hline Psychische belasting & 1 & 10 & - \\
\hline Conflicten & 0 & 4 & 4 \\
\hline \multicolumn{4}{|c|}{ Arbeidsmarktperspectieven } \\
\hline (Zeer) goede arbeidsmarktperspe & 69 & 17 & 34 \\
\hline
\end{tabular}


Tabel 3.1 (vervolg)

Employability Portfolio voor de sector Chemie, eerste invulling

\begin{tabular}{|c|c|c|c|}
\hline & Top & Bottom & Chemie \\
\hline \multicolumn{4}{|c|}{ HRM faciliteiten (top = meest aangeboden) } \\
\hline \multicolumn{4}{|l|}{ Beschikbaarheid en gebruik } \\
\hline Beschikbaarheid kinderopvang & 57 & 2 & 21 \\
\hline Gebruik kinderopvang & 13 & 5 & 9 \\
\hline Beschikbaarheid opleidingsfaciliteiten & 45 & 14 & 40 \\
\hline Opleidingsparticipatie & 67 & 35 & 48 \\
\hline Afstemming zorg en arbeid & 84 & 61 & 72 \\
\hline Functieroulatie & 90 & 54 & 90 \\
\hline Ouderenbeleid & 55 & 8 & 17 \\
\hline ARBO/verzuim & 94 & 67 & 81 \\
\hline Reïntegratie & 89 & 39 & 50 \\
\hline \multicolumn{4}{|l|}{ Kwaliteit } \\
\hline POP & $\mathrm{nb}$ & $\mathrm{nb}$ & $\mathrm{nb}$ \\
\hline Functioneringsgesprek & $\mathrm{nb}$ & $\mathrm{nb}$ & $\mathrm{nb}$ \\
\hline Ondersteuning & 88 & 65 & 66 \\
\hline \multicolumn{4}{|c|}{ Prestatiemaatstaven (top = beste prestatie) } \\
\hline Werknemerstevredenheid & $\underline{94}$ & $\underline{83}$ & $\underline{83}$ \\
\hline Verzuim & $\overline{2}$ & $\overline{7}$ & $\overline{5}$ \\
\hline Personeelsverloop & 8 & 20 & 10 \\
\hline Wervingskracht & 1,6 & 8,4 & 2,1 \\
\hline Productiviteit & \multicolumn{3}{|c|}{$\mathrm{nb}$} \\
\hline Resultaat & \multicolumn{3}{|c|}{$\mathrm{nb}$} \\
\hline $\begin{array}{l}\text { Bron: OSA/ CBS/ ROA } \\
\mathrm{nb}=\text { niet beschikbaar }\end{array}$ & & & \\
\hline
\end{tabular}

De Portfolio laat zien dat de sector Chemie op vrijwel alle indicatoren een vrij gemiddelde score heeft. De topscore heeft de sector voor de indicator functieroulatie. Dat betekent dat in veel bedrijven in de sector chemie werknemers zonder veel omschakeltijd elkaars werk overnemen, waarmee het werken aan een brede inzetbaarheid wordt gestimuleerd. Daartegenover staat wel dat de sector wordt gekenmerkt door de laagste werknemerstevredenheid. Dit laatste lijkt een belangrijk verbeterpunt. Bovendien heeft de sector chemie het hoogste verzuim vanwege conflicten met leidinggevenden of collegae. Ook dat vraagt mogelijk om extra aandacht.

\section{Handel en Reparatie}

In tabel 3.2 is een eerste invulling gegeven aan de Sectorale Employability Portfolio voor de sector Handel en Reparatie. De portfolio laat zien dat de sector Handel en Reparatie alleen op demografische ontwikkelingen de topscore heeft. Dat betekent waarschijnlijk dat de huidige vergrijzingsgraad geen aanleiding geeft om aan te 
nemen dat er een grote behoefte zal ontstaan aan employabilitybeleid dat specifiek gericht is op ouderen.

De geringe vergrijzingsgraad verklaart ook dat de aandacht voor ouderenbeleid in de sector Handel en Reparatie erg beperkt is. Weliswaar scoort de sector niet de bottomscore, maar zij zit daar niet ver boven. Wel is er in de sector sprake van een erg hoog verlooppercentage, maar liefst $20 \%$. Dat is vanzelfsprekend een belangrijk aandachtspunt voor de sector en het vraagt om nader onderzoek.

Een ander punt van aandacht is het relatief lage percentage werknemers dat werkervaring heeft opgebouwd. Waarschijnlijk hangt ook dit samen met het feit dat deze sector een relatief 'jonge' sector is, waarin veel scholieren en studenten bijbaantjes hebben (vakkenvullers, kassières e.d.). Dat zou overigens ook een verklaring kunnen zijn voor het hoge verloop binnen de sector. Een van de gesprekspartners in de sector merkt daarbij op dat juist deze gang van zaken bevreemding oproept. Enerzijds is er in de sector sprake van grote knelpunten als het gaat om het vinden van goed personeel, zeker ook voor de managementfuncties en de functie van bedrijfsleider, anderzijds beschikt de sector over een hoeveelheid jonge potentiële werknemers die nu in tijdelijke baantjes wat bijverdienen. Waarom zou de sector van dat potentieel niet beter gebruik kunnen maken door ze langer in dienst te houden, een brede ervaring te laten opbouwen en meer mogelijkheden te bieden om door te groeien naar managementfuncties. Enkele grote bedrijven in de detailhandel hebben hierop hun opleidingsprogramma en organisatie al afgestemd. Kleinere bedrijven zouden dit ook kunnen doen door bijvoorbeeld meer samen te werken aan gezamenlijk employabilitybeleid.

Tabel 3.2

Employability Portfolio voor de sector Handel en reparatie, eerste invulling

\begin{tabular}{|l|r|r|r|}
\hline \multicolumn{2}{|c|}{ Aanwezige employability (top = } & \multicolumn{1}{|c|}{ meest employable } \\
\hline \multicolumn{2}{|c|}{ Bottom } & \multicolumn{2}{l|}{$\begin{array}{l}\text { Handel en } \\
\text { reparatie }\end{array}$} \\
\hline Opleidingsniveau MBO-plus & 88 & 55 & 62 \\
\hline Werkervaring & 100 & $\underline{92}$ & $\underline{92}$ \\
\hline Ervaringsconcentratie & 17 & 39 & 25 \\
\hline Functionele mobiliteitsbereidheid & 19 & 6 & 16 \\
\hline Verhuisbereidheid & $\mathrm{nb}$ & $\mathrm{nb}$ & $\mathrm{nb}$ \\
\hline Opleidingsbereidheid & 66 & 43 & 48 \\
\hline Kwalitatieve inzetbereidheid & 85 & 65 & 75 \\
\hline Functionele mobiliteitsinspanning & $\mathrm{nb}$ & $\mathrm{nb}$ & $\mathrm{nb}$ \\
\hline Kwalitatieve inzet & 21 & 5 & 20 \\
\hline Kwantitatieve inzet & 48 & 4 & 21 \\
\hline Gezinssituatie belemmerend & 34 & 44 & 38 \\
\hline Gezondheid belemmerend & 9 & 25 & 14 \\
\hline
\end{tabular}


Tabel 3.2 (vervolg)

Employability Portfolio voor de sector Handel en reparatie, eerste invulling

\begin{tabular}{|c|c|c|c|}
\hline & Top & Bottom & $\begin{array}{l}\text { Handel en } \\
\text { reparatie }\end{array}$ \\
\hline \multicolumn{4}{|c|}{ Employability behoefte (top= minste behoefte) } \\
\hline Demografische ontwikkelingen & 0,4 & 2,9 & 0,4 \\
\hline Economische ontwikkelingen & 1,4 & 2,3 & 2,2 \\
\hline Technologische vernieuwingen & 4 & 23 & 8 \\
\hline Organisatorische veranderingen & 5 & 19 & 8 \\
\hline Fysieke belasting & 4 & 14 & 7 \\
\hline Psychische belasting & 1 & 10 & 5 \\
\hline Conflicten & 0 & 4 & 2 \\
\hline \multicolumn{4}{|c|}{ Arbeidsmarktperspectieven } \\
\hline (Zeer) goede arbeidsmarktperspectieven & 69 & 17 & 37 \\
\hline \multicolumn{4}{|c|}{ HRM faciliteiten (top = meest aangeboden) } \\
\hline \multicolumn{4}{|l|}{ Beschikbaarheid en gebruik } \\
\hline Beschikbaarheid kinderopvang & 57 & 2 & 11 \\
\hline Gebruik kinderopvang & 13 & 5 & 9 \\
\hline Beschikbaarheid opleidingsfaciliteiten & 45 & 14 & 21 \\
\hline Opleidingsparticipatie & 67 & 35 & 42 \\
\hline Afstemming zorg en arbeid & 84 & 61 & 73 \\
\hline Functieroulatie & 90 & 54 & 66 \\
\hline Ouderenbeleid & 55 & 8 & 9 \\
\hline ARBO/verzuim & 94 & 67 & 76 \\
\hline Reïntegratie & 89 & 39 & 45 \\
\hline \multicolumn{4}{|l|}{ Kwaliteit } \\
\hline POP & $\mathrm{nb}$ & $\mathrm{nb}$ & $\mathrm{nb}$ \\
\hline Functioneringsgesprek & $\mathrm{nb}$ & $\mathrm{nb}$ & $\mathrm{nb}$ \\
\hline Ondersteuning & 88 & 65 & 70 \\
\hline \multicolumn{4}{|c|}{ Prestatiemaatstaven (top = beste prestatie) } \\
\hline Werknemerstevredenheid & 94 & 83 & 92 \\
\hline Verzuim & 2 & 7 & 4 \\
\hline Personeelsverloop & $\underline{8}$ & $\underline{20}$ & $\underline{20}$ \\
\hline Wervingskracht & 1,6 & 8,4 & 5,6 \\
\hline Productiviteit & \multicolumn{3}{|c|}{$\mathrm{nb}$} \\
\hline Resultaat & \multicolumn{3}{|c|}{$\mathrm{nb}$} \\
\hline $\begin{array}{l}\text { Bron: OSA/ CBS/ ROA } \\
\mathrm{nb}=\text { niet beschikbaar }\end{array}$ & & & \\
\hline
\end{tabular}




\section{Employability Portfolio Bedrijven}

Om te kunnen bepalen in hoeverre de in hoofdstuk 3 voor de sectoren chemie en handel en reparatie ingevulde Sectorale Employability Portfolio (SEP) de basis zou kunnen vormen voor een Employability Portfolio Bedrijven (EPB) is in de gesprekken met sleutelpersonen uit de chemiesector en de detailhandel naast een bespreking van het belang van de afzonderlijke indicatoren ook afgetast in hoeverre de gewenste informatie op bedrijfsniveau beschikbaar is of kan komen. In deze gesprekken is ook nagegaan in hoeverre er behoefte bestaat aan een benchmarkinstrument waarmee individuele bedrijven in staat worden gesteld de employability situatie en ontwikkeling in hun bedrijf én het rendement van hun HRM beleid te spiegelen aan de andere bedrijven in de sector waarin zij opereren. Zoals in hoofdstuk 2 reeds werd aangegeven is ook de SEP naar aanleiding van de gevoerde gesprekken op een aantal punten gewijzigd. Op die wijzigingen is echter in hoofdstuk 2 reeds ingegaan. In dit hoofdstuk staat daarom vooral de EPB centraal.

\subsection{Employability Portfolio chemie}

Gesprekken in de sector Chemie maken allereerst duidelijk dat er veel belang wordt gehecht aan de constructie van de EPB. Eén van de argumenten daarvoor is dat het HRM beleid van bedrijven, de door de markt gedicteerde employability behoefte van het bedrijf moet volgen. Een actueel beeld van de competenties die van belang zijn voor een goede concurrentiepositie van het bedrijf is essentieel als beslist moet worden over de richting die het HRM zou moeten volgen. Té laat innoveren betekent achterop raken. Volgens enkele sleutelpersonen heeft dat bij veel bedrijven al geleid tot grote problemen.

Een belangrijk aandachtspunt voor vertegenwoordigers uit de sector Chemie is allereerst dat de organisatie in principe dusdanig vorm zou moeten krijgen dat zowel aan de leefomstandigheden van de werknemer als aan de doelstellingen van de organisatie optimaal recht wordt gedaan. Gebeurt dat niet dan worden werknemers op een ongewenste manier belast, wat uiteindelijk tot uitval kan leiden. Uitval kost veel geld en moet zoveel mogelijk voorkomen worden. Bewaking van de belasting die werknemers ervaren, de mate waarin belasting tot uitval leidt (verzuim en personeelsverloop) en de mate waarin het bieden van faciliteiten gericht op het verminderen van de negatieve gevolgen van de belasting succes heeft is daarom zeer wenselijk. Wat dat betreft biedt de EPB in combinatie met de SEP de juiste inzichten.

\section{Aanwezige employability}

Over het belang van opleidingsniveau als indicator voor de kwalificaties van werknemers in een bedrijf bestaat grote eensgezindheid onder de vertegenwoordigers van de chemiesector. De meningen over de indicator werkervaring zijn iets meer verdeeld. Argument voor het opnemen van werkervaring is dat het een belangrijke indicator is voor in de loop der tijd verworven competenties. Van de andere kant is de indicator fragiel, omdat er geen eenduidige relatie van het aantal jaren 
werkervaring met de opgebouwde employability is. Twintig jaar werkervaring kan immers ook betekenen dat iemand twintig jaar hetzelfde werk heeft gedaan. Dat is aanzienlijk minder bevorderlijk voor de employability van werkenden dan in twintig jaar tijd een aantal verschillende functies bekleden en daarbij een zeer brede ervaring opbouwen. Ervaringsconcentratie en opleidingsniveau zijn volgens vertegenwoordigers van de sector chemie betere en belangrijkere indicatoren om een beeld te krijgen van de employability van werkenden. Deze commentaren hebben ertoe geleid dat de indicatoren met betrekking tot de werkervaring van het personeel nu zijn opgedeeld in:

- $\quad$ werkervaring (\% werkenden dat langer dan 2 jaar actief is op de arbeidsmarkt);

- ervaringsconcentratie (\% werkenden dat langer dan 8 jaar in de huidige functie werkzaam is).

De eerste indicator geeft aan of werkenden op de arbeidsmarkt reeds enige vakspecifieke of algemene competenties hebben verworven. De tweede indicator wijst op de mate waarin er sprake is van ervaringsconcentratie.

Voor wat betreft de mobiliteitsbereidheid wordt aangegeven dat het interessanter zou zijn te weten welk percentage van de werkenden binnen de organisatie van baan wil veranderen. Dat cijfer zegt, volgens vertegenwoordigers van de chemiesector, meer over de in een organisatie aanwezige employability dan het percentage werkenden dat eenvoudigweg van baan wil veranderen. Functionele mobiliteitsbereidheid wordt wel gezien als een cruciale indicator, waar de overige indicatoren (opleidingsbereidheid en -inspanning, inzetbereidheid en -inspanning en belemmeringen) slechts worden gezien als 'nice to know' indicatoren.

Eén indicator zou kunnen worden toegevoegd aan de indicatorenlijst die de basis vormt voor de Bedrijvenportfolio's. Daarbij gaat het om de indicator interne mobiliteitsbereidheid. Deze (bedrijfs) interne mobiliteitsbereidheid zou moeten worden geoperationaliseerd door te kijken naar het percentage werkenden dat bereid is van baan te veranderen binnen de organisatie en daarbij niet gehinderd wordt door de verworven (arbeidsvoorwaardelijke) positie. Deze indicator kan echter vooralsnog niet worden ingevuld. De daartoe benodigde informatie is (nog) niet beschikbaar.

\section{Behoefte aan employability}

De indicatoren demografische ontwikkelingen, economische ontwikkelingen, organisatorische veranderingen en technologische vernieuwingen zijn voor de vertegenwoordigers van de chemiesector allen van groot belang als indicatoren voor de behoefte aan employability binnen bedrijven. Een kanttekening wordt geplaatst bij de manier waarop een en ander wordt geoperationaliseerd. De voorkeur gaat uit naar een operationalisatie in de trant van het percentage werknemers van wie de functie daadwerkelijk verandert als gevolg van een reorganisatie, het werken met nieuwe technieken of economische conjunctuurschommelingen. Deze informatie is echter niet beschikbaar op sectoraal niveau en vooralsnog ook niet op bedrijfsniveau. Om die reden ligt het voor de hand vooralsnog uit te gaan van de in de SEP opgenomen indicatoren, waarbij ervan wordt uitgegaan dat naarmate bepaalde ontwikkelingen 
een grotere rol spelen in een organisatie er ook meer veranderingen zijn in de functie-inhoud en functiestructuur van desbetreffende organisatie of instelling.

Hoewel vertegenwoordigers van de sector chemie aangeven dat het van groot belang is te kijken naar de mate waarin werkenden belast worden en als gevolg daarvan verzuimen, vinden zij het onderscheid tussen fysieke en psychische belasting niet nodig. Voor de EPB van de chemiesector zou dus kunnen worden overwogen deze twee indicatoren te vervangen door één indicator die informatie geeft over het percentage werkenden dat vanwege fysieke danwel psychische belasting het werk verzuimt, zodat de EPB alleen die informatie bevat die men binnen de sector ook relevant vindt.

\section{HRM faciliteiten}

Eén van de indicatoren van het HRM beleid die tijdens de gesprekken in de sector chemie als een belangrijke aanvulling werd genoemd is in de Sectorale Employability Portfolio reeds ingepast, namelijk de stijl van leiding geven. De idee dat ondersteuning van leidinggevenden essentieel is bij het vormgeven aan employabilitybeleid wordt door alle gesprekspartners gedeeld.

Alle overige HRM faciliteiten in het indicatorenstelsel voor de SEP zouden ook terug moeten komen in de EPB. De vertegenwoordigers van de chemiesector geven in ieder geval aan vrijwel alle indicatoren gebenchmarkt te willen zien. De enige indicator waarover de meningen wat verdeeld zijn is de mate waarin er gebruik gemaakt wordt van de faciliteiten voor kinderopvang. Aangenomen mag worden dat dit geheel anders ligt in sectoren waar veel vrouwen werkzaam zijn. Vooral vrouwen krijgen immers, doordat er sprake is van goede kinderopvang, bijvoorbeeld meer ruimte voor het volgen van opleidingen of het werken van meer uren. Het ligt derhalve voor de hand deze indicatoren te handhaven, in ieder geval in sectoren waar relatief veel vrouwen werkzaam zijn.

\section{Prestatiemaatstaven}

Het bepalen van het rendement van HRM investeringen door te kijken naar financieel economische kengetallen voegt volgens vertegenwoordigers van de chemiesector niet veel toe. ${ }^{17}$ Bovendien geven zij aan dat werknemers die het idee krijgen als een kostenpost te worden beschouwd snel minder gemotiveerd zullen raken en daardoor minder productief zullen zijn. De waarde van het menselijk kapitaal uit te drukken in termen van geld zou dat gevoel kunnen versterken. "Bepalen van het rendement van HRM is eerder een kwestie van gevoel. Hoe doen anderen het en wat kan ik

17. Hierbij moet wel de kanttekening worden geplaatst dat de sleutelpersonen waarmee gesproken is met name in de P\&O sfeer actief zijn. 
daarmee in mijn organisatie?" Ziekteverzuim, personeelsverloop en werknemerstevredenheid zijn daarbij belangrijker dan bijvoorbeeld omzet, winst of bijvoorbeeld een aandelenkoers.

Uit de gesprekken komt ook een aantal alternatieve prestatiemaatstaven naar voren. Allereerst is dat het gevoel van trots bij werknemers. Als voorbeeld wordt gewezen op de werknemer van DAF, die ook na het destijdse faillissement van DAF altijd een 'DAF-man' is gebleven. Dat is een duidelijke indicatie van goed HRM beleid. Tegelijk illustreert dit voorbeeld dat een sterke identificatie met het bedrijf waar iemand werkt ook een belangrijk nadeel kan vormen voor iemands employability, wanneer men op een gegeven moment genoodzaakt is elders werk te gaan zoeken. Wanneer men echter het accent zou willen leggen op de employability van het personeel binnen het bedrijf, zou deze indicator kunnen worden toegevoegd aan de EPB. Een dergelijke indicator kan gemakkelijk worden ingevuld door te kijken naar het percentage werkenden binnen een organisatie dat trots is op het feit dat zij in het bedrijf werken waar zij werken. Door in de tijd te volgen hoe dit percentage zich ontwikkelt wordt een beeld verkregen van de sterkte van de band tussen werknemers en organisatie. In de SEP zou deze indicator echter niet thuishoren. Het is echt een EPB-indicator voor bedrijven die een lange termijn relatie met hun personeel centraal willen stellen.

Het gemak waarmee werkenden binnen een organisatie een baan kunnen vinden elders in de sector of daarbuiten is volgens vertegenwoordigers van de sector eveneens een interessante indicator voor de kwaliteit van het HRM beleid binnen een organisatie. Deze indicator biedt ook een interessant tegenwicht aan de bovengenoemde indicator met betrekking tot de identificatie van werknemers met het bedrijf waar ze werken. In feite is het streven dat beide indicatoren op een zo hoog mogelijk niveau in balans zijn. Zijn werknemers immers gewild dan duidt dat op een hoge arbeidsmarktwaarde van het menselijke kapitaal en een ruime inzetbaarheid. Het wordt echter wel belangrijk gevonden dat ondanks het feit dat werkenden elders zeer gewild zijn, zij niettemin behouden blijven voor de huidige organisatie. Vertrekken de werkenden daadwerkelijk dan schiet het HRM beleid in zekere zin tekort, omdat goed HRM beleid goede werknemers 'boeit en bindt'.

In het schema 4.1 wordt mede op basis van de reacties uit de chemiesector de opzet gepresenteerd voor de EPB in de sector Chemie.

Schema 4.1

Employability Portfolio Bedrijven in de Chemiesector

\begin{tabular}{|l|l|}
\hline \multicolumn{2}{|c|}{ Opzet EPB voor de sector Chemie } \\
\hline \multicolumn{1}{|c|}{ Aanwezige employability } & \multicolumn{1}{c|}{ Operationalisatie } \\
\hline Opleidingsniveau & $\%$ werkenden met tenminste een MBO opleiding \\
\hline Werkervaring & $\begin{array}{l}\% \text { werkenden dat langer dan 2 jaar actief is op de } \\
\text { arbeidsmarkt }\end{array}$ \\
\hline Ervaringsconcentratie & $\begin{array}{l}\text { \% werkenden dat langer dan 8 jaar in de huidige } \\
\text { functie werkzaam is }\end{array}$ \\
\hline
\end{tabular}


Schema 4.1 (vervolg)

Employability Portfolio Bedrijven in de Chemiesector

\begin{tabular}{|c|c|}
\hline \multicolumn{2}{|c|}{ Opzet EPB voor de sector Chemie } \\
\hline Aanwezige employability & Operationalisatie \\
\hline Functionele mobiliteitsbereidheid & $\%$ werkenden dat van baan wil veranderen \\
\hline Verhuisbereidheid & $\begin{array}{l}\% \text { werkenden dat bereid is te verhuizen i.v.m. een } \\
\text { nieuwe functie }\end{array}$ \\
\hline Functionele mobiliteitsinspanning & $\begin{array}{l}\% \text { werkenden dat in de afgelopen twee jaar van } \\
\text { functie is veranderd }\end{array}$ \\
\hline Kwalitatieve inzet & $\begin{array}{l}\% \text { werkenden dat vaak taken op zich neemt van } \\
\text { buiten de eigen functie }\end{array}$ \\
\hline Kwantitatieve inzet & $\%$ werkenden met onregelmatige werktijden \\
\hline Gezinssituatie belemmerend & $\begin{array}{l}\% \text { werkenden gehuwd (samenwonend) met } \\
\text { thuiswonende kinderen }<17 \text { jaar }\end{array}$ \\
\hline Gezondheid belemmerend & $\begin{array}{l}\% \text { werkenden dat zich a.g.v. de gezondheid } \\
\text { belemmerd voelt bij het uitoefenen van het werk }\end{array}$ \\
\hline Employability behoefte & Operationalisatie \\
\hline Demografische ontwikkelingen & ratio van ouderen $(>=50)$ en jongeren $(<=30)$ \\
\hline Economische ontwikkelingen & $\begin{array}{l}\text { mate waarin bedrijf gevoelig is voor conjuncturele } \\
\text { schommelingen }\end{array}$ \\
\hline Technologische vernieuwingen & $\begin{array}{l}\text { \% werkenden dat met een nieuwe techniek/ } \\
\text { technologie is gaan werken }\end{array}$ \\
\hline Organisatorische veranderingen & $\begin{array}{l}\% \text { werkenden dat wordt getroffen door } \\
\text { reorganisaties }\end{array}$ \\
\hline $\begin{array}{l}\text { Verzuim vanwege belastende } \\
\text { arbeidsomstandigheden }\end{array}$ & $\begin{array}{l}\% \text { werkenden dat vanwege belasting het werk } \\
\text { verzuimt }\end{array}$ \\
\hline Arbeidsmarktperspectieven & Operationalisatie \\
\hline Arbeidsmarktperspectieven & $\begin{array}{l}\% \text { werkenden met (zeer) goede perspectieven op } \\
\text { basis van hun opleidingsachtergrond }\end{array}$ \\
\hline HRM faciliteiten & Operationalisatie \\
\hline Beschikbaarheid en gebruik & \\
\hline Beschikbaarheid kinderopvang & biedt bedrijf faciliteiten voor kinderopvang \\
\hline Gebruik kinderopvang & $\%$ werkenden dat gebruik maakt van kinderopvang \\
\hline $\begin{array}{l}\text { Beschikbaarheid } \\
\text { opleidingsfaciliteiten }\end{array}$ & heeft bedrijf een vastgesteld opleidingsbudget \\
\hline Opleidingsparticipatie & $\begin{array}{l}\% \text { werkenden dat een door de werkgever betaalde } \\
\text { opleiding heeft gevolgd }\end{array}$ \\
\hline Zorg en arbeid & $\begin{array}{l}\% \text { werkenden dat werktijden goed kan afstemmen } \\
\text { op de thuissituatie }\end{array}$ \\
\hline Functieroulatie & $\begin{array}{l}\text { voert bedrijf beleid op het gebied van taak- of } \\
\text { functieroulatie }\end{array}$ \\
\hline Ouderenbeleid & voert bedrijf ouderenbeleid \\
\hline ARBO/verzuim & heeft bedrijf ARBO/ verzuimplan uitgewerkt \\
\hline Reïntegratie & heeft bedrijf reïntegratieplan uitgewerkt \\
\hline
\end{tabular}


Schema 4.1 (vervolg)

Employability Portfolio Bedrijven in de Chemiesector

\begin{tabular}{|c|c|c|}
\hline \multicolumn{3}{|c|}{ Opzet EPB voor de sector Chemie } \\
\hline \multicolumn{3}{|l|}{ Kwaliteit } \\
\hline \multicolumn{2}{|l|}{ POP } & $\%$ werkenden waarvoor POP is opgesteld \\
\hline \multicolumn{2}{|l|}{ Functioneringsgesprek } & $\begin{array}{l}\text { \% werkenden waarmee jaarlijks } \\
\text { functioneringsgesprekken worden gevoerd }\end{array}$ \\
\hline \multicolumn{2}{|l|}{ Ondersteuning } & $\begin{array}{l}\% \text { werkenden met voldoende ondersteuning van } \\
\text { de leidinggevende }\end{array}$ \\
\hline \multicolumn{3}{|c|}{\begin{tabular}{|l|r} 
Prestatiemaatstaven & Operationalisatie \\
\end{tabular}} \\
\hline Werknemerstevredenheid & \multicolumn{2}{|c|}{$\%$ werkenden dat (zeer) tevreden is met de huidige functie } \\
\hline Verzuim & \multicolumn{2}{|c|}{ \% werkenden dat werk verzuimt, exclusief zwangerschap } \\
\hline Personeelsverloop & \multicolumn{2}{|c|}{$\%$ werkenden dat de organisatie heeft verlaten } \\
\hline Wervingskracht & \multicolumn{2}{|c|}{ \% moeilijk vervulbare vacatures op het aantal werkenden } \\
\hline Productiviteit & \multicolumn{2}{|c|}{ omzet per werkende } \\
\hline Resultaat & \multicolumn{2}{|c|}{ resultaat voor belastingheffing per werkende } \\
\hline \multicolumn{2}{|c|}{$\begin{array}{l}\text { Door de sector gewenste } \\
\text { additionele informatie }\end{array}$} & Operationalisatie \\
\hline \multicolumn{2}{|c|}{$\begin{array}{l}\text { (Bedrijfs)interne mobiliteitsbereid- } \\
\text { heid (aanwezige employability) }\end{array}$} & $\begin{array}{l}\% \text { werkenden dat bereid is van baan te } \\
\text { veranderen binnen de organisatie }\end{array}$ \\
\hline \multicolumn{2}{|l|}{$\begin{array}{l}\text { Binding aan bedrijf } \\
\text { (prestatiemaatstaf) }\end{array}$} & $\begin{array}{l}\% \text { werkenden dat er trots op is voor het bedrijf te } \\
\text { werken }\end{array}$ \\
\hline \multicolumn{2}{|c|}{$\begin{array}{l}\text { Perspectief op de arbeidsmarkt } \\
\text { (prestatiemaatstaf) }\end{array}$} & $\begin{array}{l}\% \text { werkenden dat denkt (zeer) gemakkelijk elders } \\
\text { in de sector aan de slag te kunnen }\end{array}$ \\
\hline
\end{tabular}

\subsection{Employability Portfolio detailhandel}

Gesprekken in de sector detailhandel maken duidelijk dat de sector met niet minder dan 40 brancheverenigingen een versnipperde sector is, zeker waar het het MKB betreft. Die spreiding maakt het moeilijk om voor de sector als geheel het arbeidsmarktbeleid te coördineren. Dit lijkt een belangrijk nadeel omdat de problemen voor de verschillende branches min of meer dezelfde zijn. Het tekort aan personeel wordt immers in alle branches van de detailhandel gevoeld. Vanwege de versnippering is het bovendien erg moeilijk om schaalvoordelen te behalen en is er in de praktijk weinig ruimte voor subsidieaanvragen. ${ }^{18}$ Grootwinkelbedrijven hebben deze voordelen wel en zijn mede daarom al veel verder met het ontwikkelen van bijvoorbeeld opleidingshuizen, functieprofielen, competentiedenken e.d.

Het belang van de benchmark en de daaruit voortvloeiende portfolio wordt door vertegenwoordigers van de sector detailhandel echter over het algemeen wel onderkend, zij het niet unaniem. Belangrijkste bezwaar tegen de voorgestelde opzet

18. Vanuit de detailhandel is bijvoorbeeld nog nooit subsidie aangevraagd uit het Europese Sociale Fonds. 
is dat de elementen die zullen worden gebenchmarkt de detaillisten te weinig zeggen. "De ondernemer, en vooral de ondernemer in het MKB, is gericht op het verkopen van zijn handel. Personeel is belangrijk, maar wordt voornamelijk behouden en gestimuleerd door prettig met elkaar samen te werken. De hele benchmark is daarmee leuk, maar niet nodig". Een dergelijke gedachtegang past bij uitkomsten van onderzoek van het EIM, waaruit blijkt dat vooral in familiebedrijven het voeren van formeel personeelsbeleid wordt beschouwd als een gedeeltelijk verlies van controle en flexibiliteit. ${ }^{19}$ Het belang van employability en employabilitybeleid wordt binnen het MKB in de detailhandel nauwelijks onderkend.

Eén van de argumenten die vanuit de sector worden gegeven voor het wel verder ontwikkelen van de benchmark is echter dat de portfolio inzicht geeft in de employability van het personeel en de betekenis van het HRM beleid en dat is precies de informatie die detaillisten nodig hebben om overtuigd te raken van het belang van een gezamenlijk arbeidsmarktbeleid. Wanneer door middel van gegevens in de benchmark zichtbaar wordt gemaakt wat een extra investering in bijvoorbeeld opleidingen aan omzet, werknemerstevredenheid of wervingskracht heeft opgeleverd is er voor de ondernemer houvast. Vanuit de overkoepelende branche-organisatie zou gewerkt moeten worden aan een HR instrumentarium dat aansluit bij de benchmark en dat de mogelijkheid biedt aan ondernemers om direct beleid te ontwikkelen op basis van de inzichten uit de benchmark. De benchmark is volgens sleutelfiguren in de detailhandel een uitstekende "trigger". De informatie die de benchmark via de portfolio geeft, zal de ondernemer aan het denken zetten. Daarmee kan de portfolio het startpunt vormen voor een structurele verbetering van de samenwerking binnen de sector bij het oplossen van de groeiende knelpunten in de personeelsvoorziening. De benchmark moet dan wel gericht zijn op de relatie van employability met het totale beleid van de bedrijven. De werknemers moeten in het proces nauw betrokken zijn om ook draagvlak onder personeel te creëren.

Ook wordt aangegeven dat het voor een goede employability benchmark voor de detailhandel van belang is bij de benchmarking een onderscheid te maken tussen groot, midden en kleinbedrijf. Het vergelijken van het employabilitybeleid van bedrijven met meer dan 250 medewerkers met dat van bedrijven met 15 medewerkers is immers weinig zinvol. De bedrijfsomvang zal dus als centrale invalshoek moeten worden opgenomen in de bedrijvenbenchmark.

Gesprekken leveren voorts een vijftal concrete eisen op voor een employability benchmark in de detailhandel:

- aansprekend voor het MKB;

- aanpasbaar voor branches zonder verlies van benchmarkmogelijkheden boven branches;

- gericht op zowel bedrijfsbeleid als individuele ontwikkeling van werknemers;

- aansluiting bij 'Investors in people' en INK (voorheen: Instituut Nederlandse Kwaliteit);

19. A.R. Thurik en J.M.P. de Kok (2002). Human Resource Management within small and medium-sized firms. B200103, EIM: Zoetermeer. 
- mogelijkheden creëren voor het omzetten van informatie uit de benchmark naar concrete activiteiten, bijvoorbeeld scholingsplannen of individuele leerrekeningen.

\section{Aanwezige employability}

Uit de gesprekken met de sleutelfiguren in de detailhandel komt naar voren dat, in tegenstelling tot wat de vertegenwoordigers van de chemiesector aangaven, het opleidingsniveau van de werkenden in de detailhandel veel minder belangrijk is dan de werkervaring. Enerzijds komt dat door de grote verwantschap van de functies op het lagere niveau. "Met een Mavo diploma kun je in de detailhandel je hele leven lang leuk werken". Anderzijds komt het veel voor dat werknemers in de detailhandel het werk al doende of, in familiebedrijven, van hun ouders hebben geleerd. Pas op het niveau van bedrijfsleider wordt iemands opleiding belangrijk.

Vanwege de grote overlap van de functies zegt de ervaringsconcentratie van de werkenden in de sector ook niet zoveel over hun employability. Tien jaar ervaring achter de kassa levert geen probleemsituatie op, mits werkenden meegaan met de ontwikkelingen in de functie. Veel detaillisten hebben juist behoefte aan personeel dat langere tijd op dezelfde plek wil blijven zitten. Dit bijvoorbeeld met het oog op de klantenbinding. "Daarbij komt dat veel herintredende vrouwen het juist prettig vinden om voor langere tijd hetzelfde werk te doen, mits het aansluit op de thuissituatie en men prettig kan samenwerken." Ervaringsconcentratie is in dat geval juist een bewuste keuze van werkgever en werknemer. Mede op basis van deze argumenten zijn de indicatoren werkervaring en ervaringsconcentratie al in de SEP aangepast qua operationalisatie.

Een element dat nog ontbreekt in het indicatorenstelsel is volgens een van de gesprekspartners de mate waarin de competenties van werknemers worden onderbenut. Het zou interessant zijn om structureel zicht te hebben op het aandeel van de werkenden dat het gevoel heeft onderbenut te worden. Wanneer een groot deel van de werknemers in een onderneming zich onderbenut voelt, betekent dit dat sprake is van niet gebruikte capaciteiten. Dit kan er op wijzen dat werknemers beperkt worden in de mogelijkheden om hun employability te effectueren. Om dit potentieel te activeren is een adequaat employabilitybeleid gewenst. De EPB zou dergelijke zaken moeten signaleren.

In de detailhandel wordt ook veel waarde gehecht aan de indicator voor de verhuisbereidheid. Zeker in een sector als de detailhandel is het van belang om te weten in hoeverre het personeel bereid is te reizen om op het werk te komen. Wanneer een supermarkt bijvoorbeeld een nieuwe vestiging opent en ervaren personeel in die nieuwe vestiging wil plaatsen zal eerst bekend moeten zijn of deze mensen wel elders willen werken. Volgens vertegenwoordigers van de detailhandel zou het echter beter zijn niet alleen naar het percentage werkenden dat bereid is te verhuizen voor een nieuwe functie te vragen, maar ook naar de reistijd die werkenden maximaal willen accepteren (pendelbereidheid). 


\section{Behoefte aan employability}

Over het algemeen sluiten vertegenwoordigers van de detailhandel zich aan bij in de EPB opgenomen indicatoren en de bijbehorende operationalisatie voor wat betreft de behoefte aan employability. Enkele kanttekeningen worden echter wel geplaatst. Zo lijkt het bijvoorbeeld minder zinvol te kijken naar het percentage werkenden dat betrokken is bij een reorganisatie, omdat reorganisaties niet veel voorkomen bij detaillisten en als reorganisaties al voorkomen hebben ze vrijwel altijd betrekking op alle personeelsleden. Het zou volgens vertegenwoordigers van de detailhandel beter zijn te kijken naar het percentage werkenden van wie de inhoud van de functie is gewijzigd als gevolg van organisatorische ontwikkelingen. Zoals al eerder werd aangegeven is die informatie echter niet beschikbaar. Niet op sectoraal niveau maar ook niet op bedrijfsniveau. Om de vergelijkbaarheid van de SEP en de EPB te waarborgen wordt daarom gekozen voor de oorspronkelijke operationalisatie, waarin het percentage getroffen werknemers het uitgangspunt is.

Psychische belasting is niet zo belangrijk, blijkt uit de reacties. Zeker op lager niveau (kassa, vakkenvullen, verkoper), waar verreweg de meeste werknemers werkzaam zijn, speelt psychische belasting een zeer beperkte rol. Dit beeld wordt bevestigd door cijfers van het Werkgelegenheid en Scholingsobservatorium van het ROA. ${ }^{20}$ Wel geeft men aan dat conflictsituaties en bijvoorbeeld pesten veel voorkomen. De indicator conflicten zou dan ook zeker gehandhaafd moeten worden in de EPB.

\section{HRM faciliteiten}

Omdat veel van de genoemde HRM faciliteiten CAO bepaald zijn, is de verwachting dat er in het gevoerde HRM beleid niet veel verschil zal optreden tussen de detaillisten. Voor veel van de in de SEP opgenomen indicatoren zal volgens vertegenwoordigers van de detailhandel gelden dat ze in een bepaald bedrijf ofwel voor $100 \%$ van de werknemers beschikbaar zijn of voor niemand. De elementen op zich zijn echter allemaal van groot belang. In de sector detailhandel is het overigens ook gebruikelijk om wat hoger te gaan zitten met de lonen die de CAO voorschrijft om op die manier werknemers aan te trekken en hen aan het bedrijf te binden. Het zou goed zijn dat element in ieder geval voor de sector detailhandel mee te nemen in de benchmark, bijvoorbeeld door te vragen of er lonen boven CAO schalen worden aangeboden, ja dan nee.

Voor de kleine ondernemingen is het weinig zinvol te vragen naar het percentage werkenden dat gebruik maakt van bijvoorbeeld kinderopvangregelingen. Voor het kleinbedrijf zou het beter zijn te vragen naar het al dan niet gebruiken van bepaalde regelingen. HRM faciliteiten zouden voor het kleinbedrijf in dat geval Ja/Nee indicatoren worden. Een vergelijking van de ontwikkelingen in het employabilitybeleid van een bedrijf met het sectorale beeld zou daarmee overigens niet onmogelijk worden. Het zal immers voor de individuele bedrijven belangrijk blijven om te zien of zij op 
specifieke terreinen de voorhoede vormen of juist de achterhoede en wat dat betekent.

\section{Prestatie maatstaven}

Uit de gesprekken komt naar voren dat veel belang wordt gehecht aan informatie over de doorstroom van bijvoorbeeld vakantiewerkers en weekendkrachten. Deze krachten zitten over het algemeen gewoon op school en werken daarnaast tijdelijk in de detailhandel om wat bij te verdienen. Daarbij gaat het om scholieren op bijvoorbeeld de MAVO of het VWO, maar ook om studenten die bijvoorbeeld een $\mathrm{HBO}$ of universitaire opleiding volgen. Deze groep werknemers stroomt meestal na het afronden van de opleiding uit. Volgens vertegenwoordigers van de detailhandel gaat het hierbij echter om een erg grote groep potentiële werknemers, waarvan een deel na het verlaten van de school behouden zou moeten blijven voor de sector. Daarom vinden zij het van groot belang om meer inzicht te krijgen in de mate waarin hulpkrachten uiteindelijk instromen in de organisatie. Deze indicator is daarom ook opgenomen in de EPB voor de detailhandel. Zij is geoperationaliseerd als het percentage hulparbeiders dat na afloop van de schoolloopbaan instroomt in de organisatie.

Ten slotte wordt uit de gesprekken duidelijk dat behalve de werknemerstevredenheid, zeker voor de detailhandel, ook de klanttevredenheid een belangrijke prestatiemaatstaf is. Deze indicator kan volgens de vertegenwoordigers van de sector het best worden geoperationaliseerd door te kijken naar het percentage klanten dat (zeer) tevreden is over de manier waarop een bedrijf service verleent.

In schema 4.2 wordt de opzet voor de EPB in de detailhandel gepresenteerd. Deze is opgesteld op basis van de SEP en de gesprekken, zoals ze in deze paragraaf zijn besproken.

Schema 4.2

Employability Portfolio Bedrijven in de Detailhandel

\begin{tabular}{|c|c|}
\hline \multicolumn{2}{|c|}{ Opzet EPB voor de Detailhandel } \\
\hline Aanwezige employability & Operationalisatie \\
\hline Opleidingsniveau & $\%$ werkenden met tenminste een MBO opleiding \\
\hline Werkervaring & $\begin{array}{l}\% \text { werkenden dat langer dan } 2 \text { jaar actief is op de } \\
\text { arbeidsmarkt }\end{array}$ \\
\hline Ervaringsconcentratie & $\begin{array}{l}\% \text { werkenden dat langer dan } 8 \text { jaar in de huidige } \\
\text { functie werkzaam is }\end{array}$ \\
\hline Functionele mobiliteitsbereidheid & $\%$ werkenden dat van baan wil veranderen \\
\hline Verhuisbereidheid & $\begin{array}{l}\% \text { werkenden dat bereid is te verhuizen i.v.m. een } \\
\text { nieuwe functie }\end{array}$ \\
\hline Opleidingsbereidheid & $\begin{array}{l}\text { \% werkenden dat een opleiding heeft gevolgd in } \\
\text { de afgelopen } 2 \text { jaar }\end{array}$ \\
\hline Kwalitatieve inzetbereidheid & $\begin{array}{l}\% \text { werkenden dat indien nodig taken van buiten de } \\
\text { functie op zich zou willen nemen }\end{array}$ \\
\hline
\end{tabular}


Schema 4.2 (vervolg)

Employability Portfolio Bedrijven in de Detailhandel

\begin{tabular}{|c|c|c|}
\hline \multicolumn{3}{|c|}{ Opzet EPB voor de Detailhandel } \\
\hline \multicolumn{2}{|c|}{ Aanwezige employability } & Operationalisatie \\
\hline \multicolumn{2}{|l|}{ Functionele mobiliteitsinspanning } & $\begin{array}{l}\text { \% werkenden dat in de afgelopen twee jaar van } \\
\text { functie is veranderd }\end{array}$ \\
\hline \multicolumn{2}{|l|}{ Kwalitatieve inzet } & $\begin{array}{l}\text { \% werkenden dat vaak taken op zich neemt van } \\
\text { buiten de eigen functie }\end{array}$ \\
\hline \multicolumn{2}{|l|}{ Kwantitatieve inzet } & $\%$ werkenden met onregelmatige werktijden \\
\hline \multicolumn{2}{|l|}{ Gezinssituatie belemmerend } & $\begin{array}{l}\% \text { werkenden gehuwd (samenwonend) met } \\
\text { thuiswonende kinderen }<17 \text { jaar }\end{array}$ \\
\hline \multicolumn{2}{|l|}{ Gezondheid belemmerend } & $\begin{array}{l}\text { \% werkenden dat zich a.g.v. de gezondheid } \\
\text { belemmerd voelt bij het uitoefenen van het werk }\end{array}$ \\
\hline \multicolumn{2}{|l|}{ Employability behoefte } & Operationalisatie \\
\hline \multicolumn{2}{|l|}{ Demografische ontwikkelingen } & Ratio van ouderen $(>=50)$ en jongeren $(<=30)$ \\
\hline \multicolumn{2}{|l|}{ Economische ontwikkelingen } & $\begin{array}{l}\text { Mate waarin bedrijf gevoelig is voor } \\
\text { conjuncturele schommelingen }\end{array}$ \\
\hline \multicolumn{2}{|l|}{ Technologische vernieuwingen } & $\begin{array}{l}\% \text { werkenden dat met een nieuwe techniek/ } \\
\text { technologie is gaan werken }\end{array}$ \\
\hline \multicolumn{2}{|l|}{ Organisatorische veranderingen } & $\begin{array}{l}\% \text { werkenden dat wordt getroffen door } \\
\text { reorganisaties }\end{array}$ \\
\hline \multicolumn{2}{|l|}{$\begin{array}{l}\text { Verzuim vanwege belastende } \\
\text { arbeidsomstandigheden }\end{array}$} & $\begin{array}{l}\% \text { werkenden dat vanwege fysieke of } \\
\text { psychische belasting het werk verzuimt }\end{array}$ \\
\hline \multicolumn{2}{|c|}{ Arbeidsmarktperspectieven } & Operationalisatie \\
\hline \multicolumn{2}{|c|}{ Arbeidsmarktperspectieven } & $\begin{array}{l}\% \text { werkenden met (zeer) goede perspectieven } \\
\text { op basis van hun opleidingsachtergrond }\end{array}$ \\
\hline HRM faciliteiten & & Operationalisatie \\
\hline \multicolumn{3}{|l|}{ Beschikbaarheid en gebruik } \\
\hline $\begin{array}{l}\text { Beschikbaarheid } \\
\text { kinderopvang }\end{array}$ & \multicolumn{2}{|c|}{ biedt bedrijf faciliteiten voor kinderopvang } \\
\hline Gebruik kinderopvang & \multicolumn{2}{|c|}{$\%$ werkenden dat gebruik maakt van kinderopvang } \\
\hline $\begin{array}{l}\text { Beschikbaarheid } \\
\text { opleidingsfaciliteiten }\end{array}$ & \multicolumn{2}{|c|}{ heeft bedrijf een vastgesteld opleidingsbudget } \\
\hline Opleidingsparticipatie & \multicolumn{2}{|c|}{$\begin{array}{l}\% \text { werkenden dat een door de werkgever betaalde } \\
\text { opleiding heeft gevolgd }\end{array}$} \\
\hline Zorg en arbeid & \multicolumn{2}{|c|}{$\begin{array}{l}\text { \% werkenden dat werktijden goed kan afstemmen op de } \\
\text { thuissituatie }\end{array}$} \\
\hline Functieroulatie & \multicolumn{2}{|c|}{$\begin{array}{l}\text { voert bedrijf beleid op het gebied van taak- of } \\
\text { functieroulatie }\end{array}$} \\
\hline Ouderenbeleid & \multicolumn{2}{|c|}{ voert bedrijf ouderenbeleid } \\
\hline ARBO/verzuim & \multicolumn{2}{|c|}{ heeft bedrijf ARBO/ verzuimplan uitgewerkt } \\
\hline Reïntegratie & \multicolumn{2}{|c|}{ heeft bedrijf reïntegratieplan uitgewerkt } \\
\hline
\end{tabular}


Schema 4.2 (vervolg)

Employability Portfolio Bedrijven in de Detailhandel

\begin{tabular}{|c|c|c|}
\hline \multicolumn{3}{|c|}{ Opzet EPB voor de Detailhandel } \\
\hline HRM faciliteiten & & Operationalisatie \\
\hline \multicolumn{3}{|l|}{ Kwaliteit } \\
\hline POP & \multicolumn{2}{|c|}{$\%$ werkenden waarvoor POP is opgesteld } \\
\hline Functioneringsgesprek & \multicolumn{2}{|c|}{$\begin{array}{l}\% \text { werkenden waarmee jaarlijks functioneringsgesprekken } \\
\text { worden gevoerd }\end{array}$} \\
\hline Ondersteuning & \multicolumn{2}{|c|}{$\begin{array}{l}\% \text { werkenden met voldoende ondersteuning van de } \\
\text { leidinggevende }\end{array}$} \\
\hline Prestatiemaatstaven & \multicolumn{2}{|r|}{ Operationalisatie } \\
\hline Werknemerstevredenheid & \multicolumn{2}{|c|}{$\%$ werkenden dat (zeer) tevreden is met de huidige functie } \\
\hline Verzuim & \multicolumn{2}{|c|}{$\%$ werkenden dat werk verzuimt, exclusief zwangerschap } \\
\hline Personeelsverloop & \multicolumn{2}{|c|}{$\%$ werkenden dat de organisatie heeft verlaten } \\
\hline Wervingskracht & \multicolumn{2}{|c|}{$\%$ moeilijk vervulbare vacatures op het aantal werkenden } \\
\hline Productiviteit & \multicolumn{2}{|c|}{ omzet per werkende } \\
\hline Resultaat & \multicolumn{2}{|c|}{ resultaat voor belastingheffing per werkende } \\
\hline \multicolumn{2}{|c|}{$\begin{array}{l}\text { Door de sector gewenste } \\
\text { informatie }\end{array}$} & Operationalisatie \\
\hline \multicolumn{2}{|c|}{ Bedrijfsomvang (controle variabele) } & aantal werkenden \\
\hline \multicolumn{2}{|l|}{$\begin{array}{l}\text { Onderbenutting (aanwezige } \\
\text { employability) }\end{array}$} & $\begin{array}{l}\% \text { werkenden dat vindt dat competenties } \\
\text { onvoldoende worden benut }\end{array}$ \\
\hline \multicolumn{2}{|l|}{$\begin{array}{l}\text { Pendelbereidheid (aanwezige } \\
\text { employability) }\end{array}$} & $\begin{array}{l}\text { maximale reistijd die werknemers willen } \\
\text { accepteren }\end{array}$ \\
\hline \multicolumn{2}{|c|}{ Loon boven CAO (HRM faciliteiten) } & $\begin{array}{l}\text { \% werkenden met een loon dat hoger is dan het } \\
\text { volgens de CAO verplichte loon }\end{array}$ \\
\hline \multicolumn{2}{|l|}{$\begin{array}{l}\text { Doorstroom hulparbeiders } \\
\text { (prestatiemaatstaf) }\end{array}$} & $\begin{array}{l}\% \text { hulparbeiders (weekendhulp, vakantiekracht } \\
\text { etc.) dat ook na afronding van de studie in dienst } \\
\text { blijft }\end{array}$ \\
\hline \multicolumn{2}{|c|}{ Klanttevredenheid (prestatiemaatstaf) } & $\begin{array}{l}\% \text { klanten dat tevreden is over de } \\
\text { dienstverlening van het bedrijf }\end{array}$ \\
\hline
\end{tabular}

\subsection{Positionering van de Employability Portfolio's}

De laatste jaren wordt in Nederland meer en meer aandacht besteed aan employability. Vakbonden, werkgeversverenigingen, organisatie-adviesbureaus en branche-organisaties hebben inmiddels verschillende instrumenten ontwikkeld om bijvoorbeeld de employability binnen bedrijven of branches te bepalen en te volgen. De vraag wat de toegevoegde waarde is van de in dit rapport ontwikkelde Sectorale Employability Portfolio en Employability Portfolio Bedrijven ten opzichte van andere 'employability scans' is daarom een zeer legitieme. Om een antwoord te geven op deze vraag is het van belang te kijken naar andere instrumenten en deze met elkaar 
te vergelijken. In deze paragraaf wordt kort ingegaan op:

- het CNV-onderzoek Op Koers naar employability;

- de employability scan van Syntens ;

- het pilotproject employability in de detailhandel in Limburg ("Je toekomst in de winkel") van de Stichting Arbeidsmarkt MKB.

\section{CNV Op Koers ${ }^{21}$}

Het CNV startte in 1999 met een groots opgezet en meerjarig onderzoek naar de mogelijkheden voor employability binnen een aantal organisaties uit diverse sectoren. Het doel was het in beeld brengen van de employability activiteiten die in Nederland plaatsvinden. De benodigde informatie werd verzameld door drie partijen te betrekken in het onderzoek: een vertegenwoordiger van $\mathrm{P} \& \mathrm{O}$, de Ondernemingsraad of Medezeggenschapsraad en de individuele werknemer.

CNV ontwikkelde een test waarmee gemakkelijk inzicht kan worden verkregen in de employability situatie binnen organisaties. De test kent een drietal centrale elementen:

- toekomstverwachting/ noodzaak employability;

- employabilitybeleid;

- employabilitycultuur.

Het element "Toekomstverwachting" is te vergelijken met de dimensie "Behoefte aan employability" in het indicatorenstelsel en betreft veranderingen die in de komende jaren verwacht worden. In de test komen de ontwikkeling van de werkgelegenheid en organisatorische veranderingen terug. De behoefte aan employability vanwege technologische vernieuwingen, demografische ontwikkelingen of arbeidsomstandigheden vormt daarentegen geen onderdeel van de CNV-test.

Het element "Employabilitybeleid" is te vergelijken met de dimensie HRM faciliteiten in de in dit rapport gepresenteerde Employability Portfolio's. De beschikbaarheid van opleidingsfaciliteiten, functioneringsgesprekken, POP's en bijvoorbeeld functieroulatie komen ook in de CNV test terug. Aan het feitelijke gebruik van de aangeboden faciliteiten wordt daarentegen geen aandacht besteed. Aspecten als kinderopvang en afstemming van arbeid en zorg ontbreken ook in de CNV-test.

Employabilitycultuur, het derde element in de CNV-test, komt niet als aparte dimensie terug in de Employability Portfolio's. Dit is een bewuste keuze geweest. De aanwezigheid van een employabilitycultuur kan immers worden afgeleid uit de mate waarin er faciliteiten door organisaties worden aangeboden en de mate waarin deze faciliteiten door werknemers worden aangegrepen om hun employability te versterken. Deze elementen worden door het indicatorenstelsel goed afgedekt.

21. Zie ook CNV (2002). Employability Op Koers, aanzet tot strategisch personeelsbeleid. Vakcentrale CNV: Utrecht. 


\section{Syntens' Employability Scan}

Syntens ontwikkelde de Employability Scan om vooral MKB ondernemers te ondersteunen bij het vergroten van de employability van hun personeel. De scan brengt in principe in beeld wat een ondernemer nodig heeft om zijn bedrijf verder te ontwikkelen. Na probleemherkenning, analyse en conclusies en samenvatting mondt de scan uit in een actieplan dat onder begeleiding van een employability adviseur wordt uitgevoerd. De scan van Syntens beslaat een breed spectrum van relevante onderwerpen onder te verdelen in 9 dimensies, te weten:

- innovatiestrategie;

- toekomstperspectief;

- algemeen beleid;

- leidinggeven, motiveren, communiceren;

- functioneren en beoordelen;

- scholen en opleiden;

- competentie ontwikkeling;

- arbeidssituatie;

- attitude.

De eerste drie dimensies zijn bedoeld om te inventariseren waar een bedrijf staat qua structuur, hiërarchie en toekomstverwachting. Hiermee wordt in feite geprobeerd de behoefte aan employability in beeld te brengen. In tegenstelling tot de Employability Portfolio die wij hier voorstellen gebeurt dit door middel van open vragen. Vanuit de doelstelling om individuele bedrijven te begeleiden in hun employabilitybeleid is de Syntens benadering waarschijnlijk een goede benadering. Als instrument voor benchmarking zijn dergelijke open vragen echter niet geschikt.

De overige dimensies zijn bedoeld om het personeelsbeleid in beeld te brengen. Ook hierbij worden open vragen gesteld. De dimensies beslaan feitelijk de in de SEP onderscheiden HRM faciliteiten en de aanwezige employability, zij het dat niet elke indicator in beide instrumenten terugkomt. Bovendien hanteert Syntens een andere systematiek, waarbij per beleidsterrein informatie wordt verzameld over uiteenlopende zaken. Zo wordt bijvoorbeeld onder de noemer leiding geven, motiveren en communiceren gevraagd naar:

- het verloop (in de Employability Portfolio een prestatiemaatstaf);

- de mate waarin werknemers elkaars werk overnemen (in de Employability Portfolio een indicator van de aanwezige employability);

- de mate waarin het bedrijf investeert in ziekteverzuimbeleid (in de Employability Portfolio een HRM faciliteit).

Voor wat betreft de verzamelde informatie is er in het algemeen wel een grote overlap tussen de Syntens Scan en de Employability Portfolio's.

Belangrijk verschil is dat Syntens de informatie via kwalitatief onderzoek verzamelt terwijl in de Employability Portfolio's de nadruk ligt op kwantitatief, gemakkelijk te benchmarken, cijfermateriaal. Bovendien is de scan van Syntens een instrument dat zich alleen maar richt op individuele bedrijven, terwijl de Employability Portfolio 
gericht is op zowel de individuele bedrijven als de sectoren waarin zij opereren. Daarmee zijn de beide Employability Portfolio's voor zowel bedrijven zelf als voor de overheid en branche- en sectorvertegenwoordigende organen bruikbare benchmarkinstrumenten. Niet alleen om de status-quo van het employabilitybeleid te beoordelen en vergelijken maar ook om de ontwikkelingen daarin en de resultaten ervan in de tijd te volgen. Voor een positionering van individuele bedrijven binnen hun sector kan overigens met de via de Syntens-scan verzamelde informatie aansluiting worden gezocht bij de EPB. Omdat Syntens zich echter niet bezighoudt met de detailhandel is aansluiting bij hun benadering bij invulling van de EPB's binnen die branche vooralsnog niet mogelijk.

\section{Pilotproject employability in de detailhandel in Limburg}

Het project "Je toekomst in de winkel" is opgezet op initiatief van het Vertrouwenspact Werkgelegenheid Limburg. Het wordt gefinancierd door het ministerie van SZW, de provincie Limburg en het bedrijfsleven in de detailhandel zelf. Het project wordt uitgevoerd in opdracht van de stichting Arbeidsmarkt MKB in Venlo met ondersteuning van het Kenniscentrum Handel in Ede. Het gaat vooralsnog om een pilotproject gericht op de monitoring van employability in de detailhandel in Limburg.

In het project worden ca. 50 bedrijven (tussen 10 en 250 werknemers) doorgelicht op thema's als strategie, HRM-beleid, communicatie, kwaliteitsbeleid en arbo- en gezondheidsbeleid. Ook alle werknemers worden betrokken bij de doorlichting. Dit gebeurt door middel van een individuele scan, waarin de mening van de werknemers wordt gevraagd over zowel het functioneren van het bedrijf als de eigen ontwikkeling.

Het project heeft primair tot doel om ervaring op te doen met de sensibilisering van de ondernemers en werknemers in het MKB in de detailhandel op het gebied van HRM en employability. Verder is het de bedoeling om de instrumenten die worden ontwikkeld voor de detailhandel ook buiten Limburg en voor andere MKB-bedrijven in en buiten Limburg te gaan inzetten.

De basis van het pilotproject ligt in het bedrijfsmodel van het Health Management Institute, in Nederland gerepresenteerd door de Stichting Gezondheidsbevordering op de Werkplek (GBW). Dit model is erop gericht een bedrijf door te lichten op een viertal aspecten:

- $\quad$ kwaliteitsbeleid (effectiviteit van werknemers);

- $\quad$ motivatiebeleid (gekoppeld aan employability);

- gezondheidsbeleid;

- $\quad$ bedrijfscultuur (werkplezier).

Doel is harmonisering van deze vier aspecten onder de voorwaarde dat ook kosten en baten de juiste verhouding hebben. De kosten van het in dienst hebben van personeel worden in het pilotproject globaal ingeschat om voor ondernemers de kosten van suboptimaal employability beleid zichtbaar te maken. Zo zou zichtbaar kunnen worden wat $1 \%$ extra verzuim in euro's nu eigenlijk kost, maar ook wat een arbeidsconflict voor kosten met zich meebrengt. Hiermee raakt de benadering die in 
dit pilotproject is gekozen zeer nauw aan de benadering van Syntens, waar ook wordt ingestoken op het niveau van de individuele bedrijven. Verschil is echter wel dat veel minder gebruik wordt gemaakt van open vragen en dat dus de verzamelde informatie van verschillende bedrijven over het algemeen onderling wat beter te vergelijken is.

In relatie tot de Employability Portfolio Bedrijven is ook het pilotproject echter veel meer een branche-project dan een branche- en sectoroverstijgend instrument waarmee individuele bedrijven zich binnen de eigen sector zouden kunnen positioneren en waarmee de ontwikkeling van de employability situatie en de effecten van HRM beleid in de tijd zouden kunnen worden gevolgd.

Het pilotproject heeft overigens ook een grote waarde als het gaat om het creëren van draagvlak bij ondernemers in de detailhandel voor structurele aandacht voor employability en HRM. Dit draagvlak is nodig om de Employability Portfolio tot een succesvol instrument te kunnen maken.

\subsection{Mogelijkheden voor implementatie Employability Portfolio}

Om de Employability Portfolio te kunnen implementeren is het vanzelfsprekend noodzakelijk dat er in de verschillende bedrijfssectoren en bedrijven voldoende draagvlak voor is. Wat dat betreft kan geconcludeerd worden dat de employability portfolio goed aansluit bij het in veel branches de laatste jaren sterk toegenomen besef van het belang van een goed employabilitybeleid. Daarbij is er soms nog wel enige aarzeling voor zover een goede employability van werkenden betekent dat voor het bedrijf waardevolle arbeidskrachten sneller naar een ander bedrijf overstappen.

Zowel in de chemie als in de detailhandel bestaat duidelijke belangstelling voor het ontwikkelen van een benchmarkinstrument op dit terrein. Cruciaal voor een goede implementatie van de Employability Portfolio is echter dat de belasting die het voor bedrijven met zich meebrengt om de vereiste informatie aan te leveren zoveel mogelijk wordt beperkt. Wat dat betreft kunnen de in dit rapport gepresenteerde Employability Portfolio's ook worden gezien als een lijst van in principe relevante indicatoren waaruit een bedrijfssector een keuze kan maken of bepaalde accenten kan leggen.

Er zijn in principe twee mogelijkheden om de voor de Employability Portfolio vereiste informatie te verzamelen:

- $\quad$ aanlevering door de bedrijven zelf door een employability enquête uit te zetten onder degenen die in het bedrijf verantwoordelijk zijn voor het personeelsbeleid, bij voorkeur aangevuld met een enquête onder (een deel van) het personeel;

- $\quad$ verzameling van de vereiste informatie via employability consultants. 


\section{Employability enquête}

De eerste optie is waarschijnlijk vooral interessant voor sectoren waarin relatief veel grote bedrijven actief zijn, zoals bijvoorbeeld de chemiesector. Niet alleen hebben grotere bedrijven professionele P\&O'ers in dienst die vaak veel belangstelling hebben voor de employabilityproblematiek, ook beschikken grotere bedrijven vaak over (meer) en gemakkelijker toegankelijke administratieve gegevens over hun personeel. Invullen van een enquête is daardoor eenvoudiger en dus minder belastend.

De Employability enquête kan ook aanhaken bij bestaande arbeidsmarktmonitoren. De voor de Employability Portfolio vereiste informatie zou bijvoorbeeld verzameld kunnen worden door middel van de Arbeidsmarktmonitor Metalektro. Deze monitor is door het ROA in samenwerking met Center-data en ORBIS in opdracht van het A+Ofonds Metalektro opgezet. In het kader van deze arbeidsmarktmonitor beantwoorden de hoofden P\&O van een groot aantal bedrijven in de metaal en elektrotechniek vier maal per jaar via internet een korte vragenlijst. Deze vragenlijst richt zich op een viertal aandachtspunten:

- de knelpunten op de arbeidsmarkt;

- de verschuivingen in de gevraagde competenties;

- de instroom en uitstroom van personeel;

- de employability van het personeel.

De informatie die in deze en andere arbeidsmarktmonitoren wordt verzameld is vaak vooral sectorspecifiek van aard. Afstemming met het conceptuele model voor de Employability Portfolio is derhalve noodzakelijk. Voor de sector metaal- en elektrotechniek zouden kleine aanpassingen in de vragenlijsten echter al voldoende zijn om de invulling van de Employability Portfolio's mogelijk te maken.

\section{Informatieverzameling via consultants}

Men name voor sectoren waar veel kleine en middelgrote bedrijven actief zijn, zoals de detailhandel, zou de informatie die vereist is voor de employability portfolio van het bedrijf waarschijnlijk het beste verzameld kunnen worden door employability consultants. Hierbij zou goed kunnen worden aangesloten bij bestaande informatiekanalen. Het initiatief hiervoor zou in principe moeten liggen bij branche- of sectorvertegenwoordigende organisaties. Het Pilotproject employability in de detailhandel in Limburg is een uitstekend voorbeeld van een dergelijk initiatief. Ook zou gedacht kunnen worden aan de consultants die opereren vanuit bedrijfstakorganisaties of de consultants van de Kenniscentra Beroepsonderwijs Bedrijfsleven (KBB's). Belangrijk voor een optimale invulling van de Employability Portfolio's is echter wel dat afgezien van de mogelijkheid voor sectorspecifieke accenten in principe in álle sectoren en branches vergelijkbare informatie wordt verzameld. Enige centrale coördinatie is daarbij van groot belang. 


\section{Pilotprojecten}

In principe zouden langs beide lijnen pilotprojecten kunnen worden gestart. Hoewel er altijd sprake zal zijn van sectorspecifieke factoren die van belang zijn voor een goede Employability Portfolio, zouden deze pilotprojecten als een 'best practice' kunnen fungeren dat door andere sectoren kan worden overgenomen. In pilotprojecten zou overigens ook aansluiting kunnen worden gezocht bij het Investors in People certificatietraject.

Het is wenselijk om alle doelgroepen op macro, meso en micro-niveau die belang hebben bij het tot stand komen van Employability Portfolio's bij deze pilotprojecten te betrekken. Daarbij gaat het, zoals gezegd, om de gebruikers van de informatie op drie niveaus; het sociaal-economische c.q. arbeidsmarktbeleid (overheid en sociale partners), bedrijfstakken (branchegenoten, sociale partners) en individuele bedrijven (directie, HRM functionarissen, Ondernemingsraad). 


\section{Literatuur}

Arbeidsinspectie (2001), Najaarsrapportage CAO-afspraken 2001. Den Haag: Arbeidsinspectie.

Buchel, Y. (2002). Persoonlijke ontwikkelingsplannen in de praktijk. Gids voor Personeelsmanagement. Vol. 81, 1, pp.51-53.

CNV (2002). Employability Op Koers, aanzet tot strategisch personeelsbeleid. Utrecht: Vakcentrale CNV.

Grip, A. de, J.B. van Loo \& J.M.A.F. Sanders (1998), Employability in bedrijf: naar een Employability Index voor bedrijfssectoren. ROA-R-1998/10, Maastricht.

Grip, A. de \& J.M.A.F. Sanders (2001). Naar een Employability Monitor, Ministerie van Sociale Zaken en Werkgelegenheid, Doetinchem: Elsevier Bedrijfsinformatie.

Kok, de J.M.P. (2000). The impact of firm-provided training on production: testing for firm-size effects. Tinbergen Institute discussion paper 00-073/3, Amsterdam/Rotterdam: Tinbergen Instituut.

Loo, J.B. van \& A. de Grip (2002). Loont HRM? Een literatuurverkenning. ROA-R-2002/15, Maastricht.

Loo, J.B. van \& A. de Grip (2003). Loont het investeren in het personeel? ROA-R-2003/1, Maastricht.

Meer, van der B. (1997). Pesten op het werk. Assen: Van Gorcum.

Ministerie van Economische Zaken (2000), Toets op het concurrentievermogen: op de drempel van het nieuwe millennium. Den Haag: SDU Uitgevers.

ROA (2002), Werkgelegenheid en scholing 2001, ROA-R-2002/7, Maastricht.

Thijssen, J.G.L. (1989), Bedrijfsopleidingen als werkterrein: een oriëntatie, VUGA, Den Haag.

Thurik, A.R. \& J.M.P. de Kok (2002), Human Resource Management within small and mediumsized firms. Zoetermeer: EIM. 